مرورى جامع بر آلكالوئيدهاى ارزشمند ترويانى: اسكويلامين، آترويين و هيوسيامين

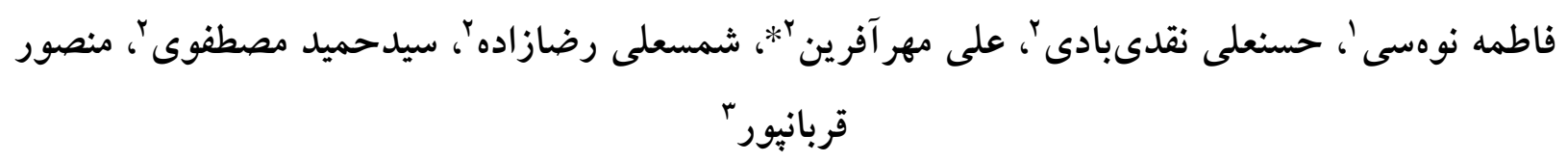

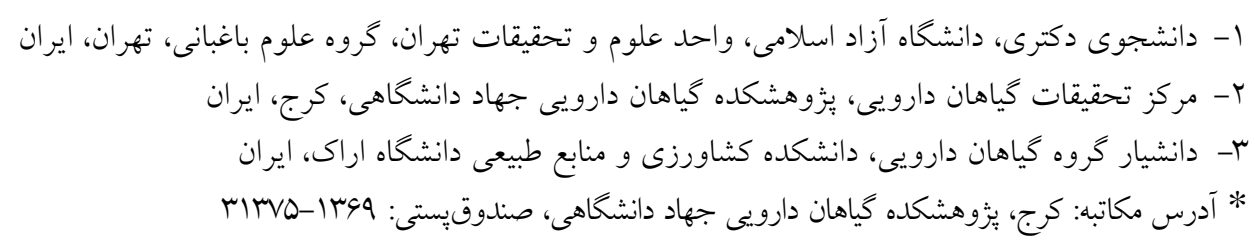

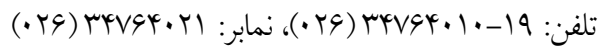

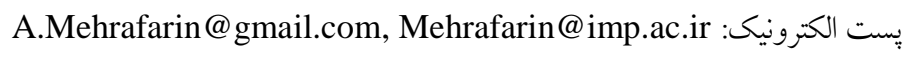

doi: $10.29252 / j m p .2 .70 .21$ qV/1./IV تاريخ تصويب

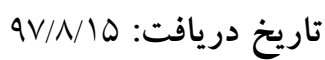

آلكالوئيدهاى ترويانى نظير اسكويو لامين (آن (C)

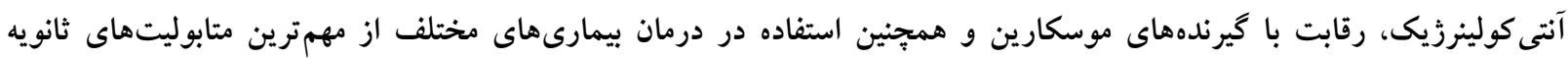

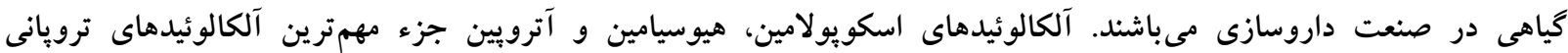

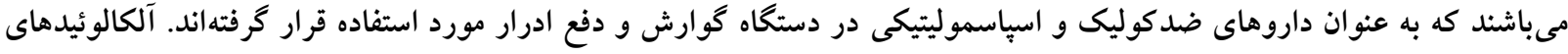

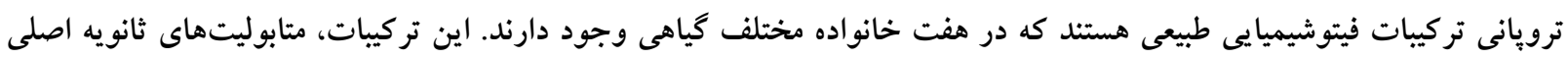

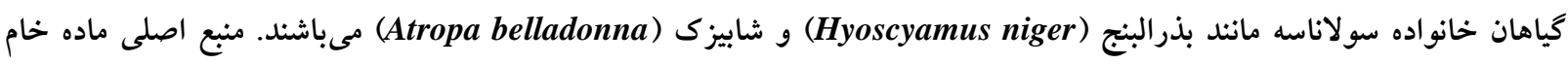

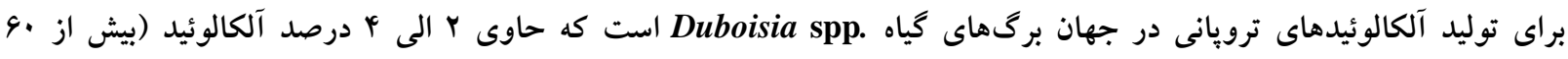

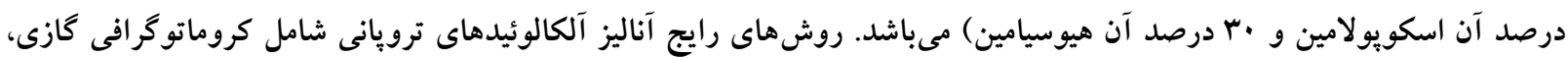

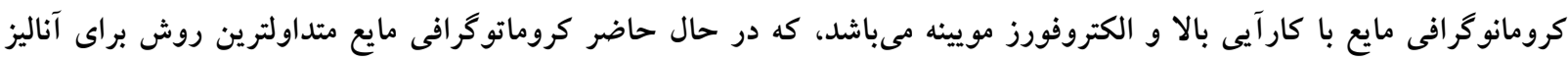

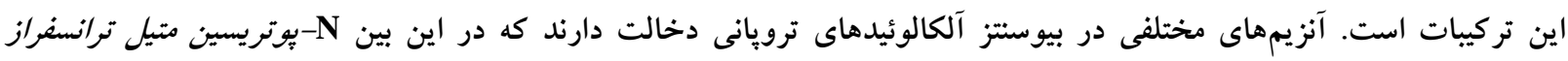

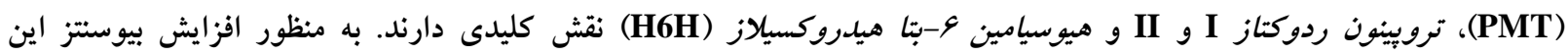

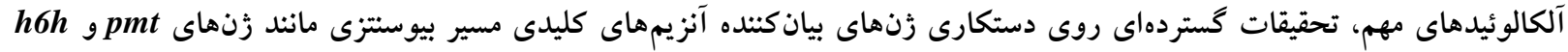

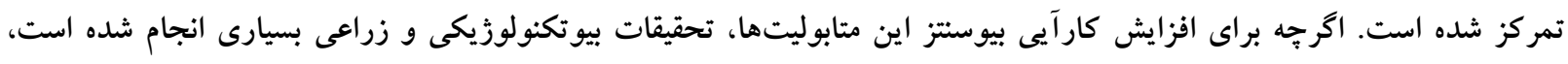

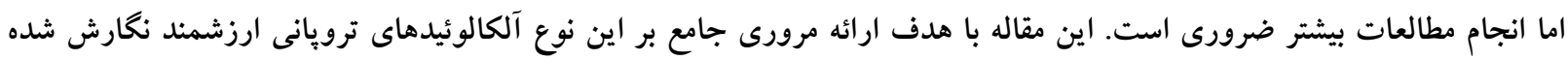
كل واز كان: آترويين، آلكالوئيدهاى ترويانى، اسكويولامين، هيوسيامين 
اين تركيبات داراى يك اتم نيتروزن در يكى سيستم

هتروسيكليك هستند، كه از آمينواسيد مربوطه طى فئ فر آيند

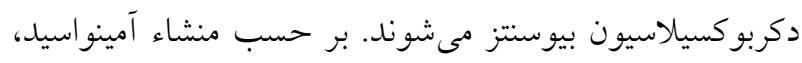

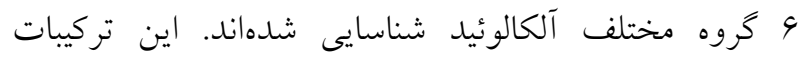

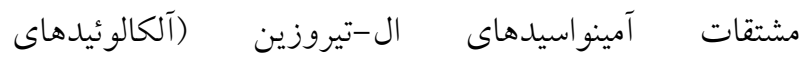

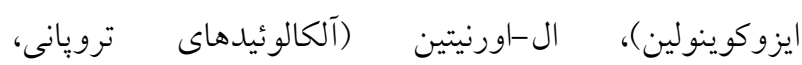

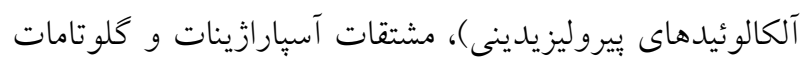

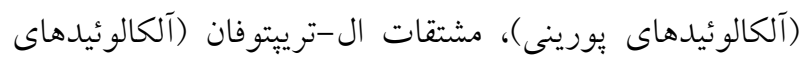

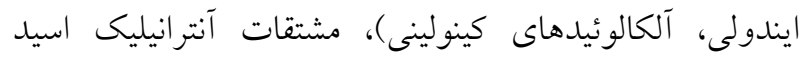

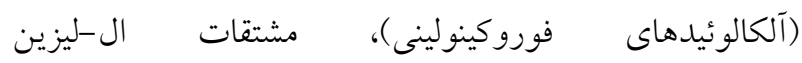

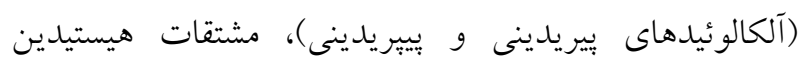

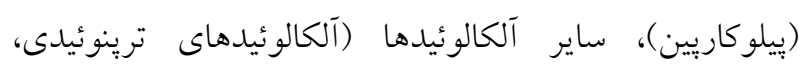
آلكالوئيدهاى استروئيدى) [بائ).

\section{ب) آلكالوئيدهاى غيرهتروسيكليك (Nonheterocyclic Alkaloids)}

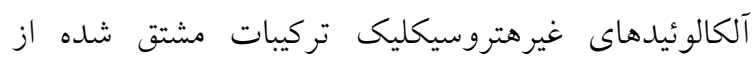

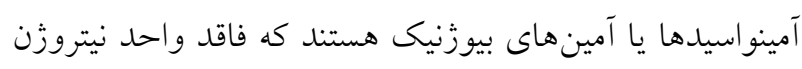

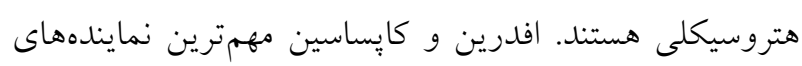

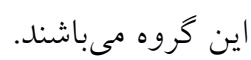

\section{آلكالوئيدهاى ترويانى}

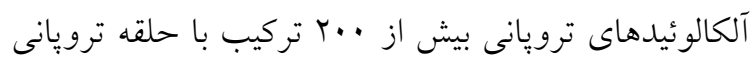

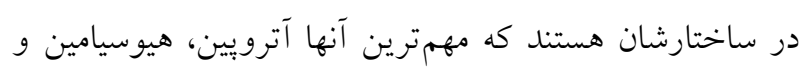

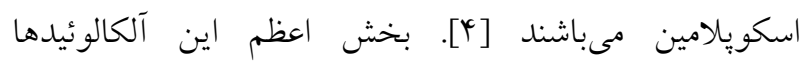

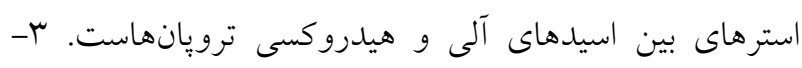

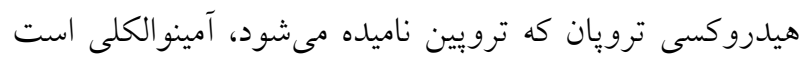

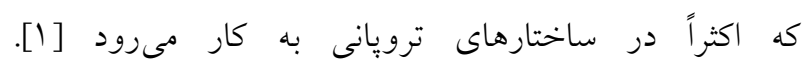

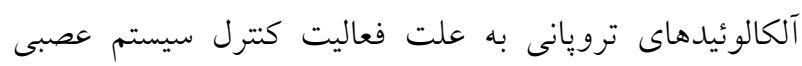
(CNS)

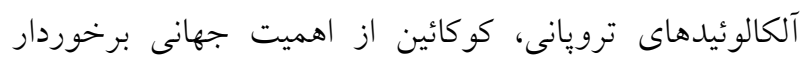

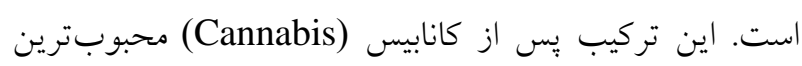

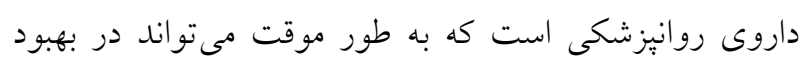

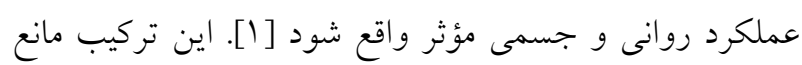

با افزايش مصرف داروهاى با منشاء گياهى در جامعه و

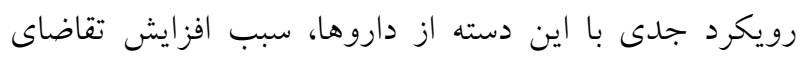

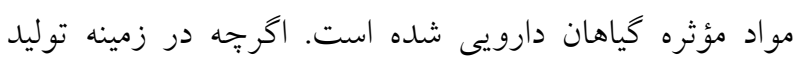
مواد مؤثره گياهى به روش سنتيكى ييشرفت هايى حاصل شده

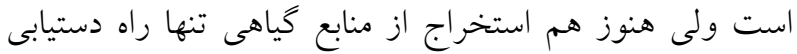
به بسيارى از اين مواد دارويى ارزشمند است. زيرا مواد مؤثره

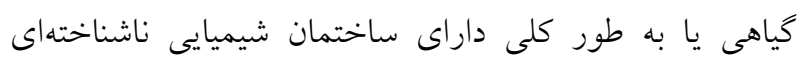

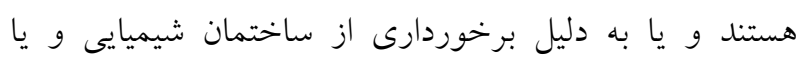

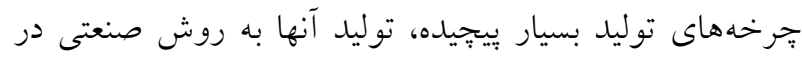

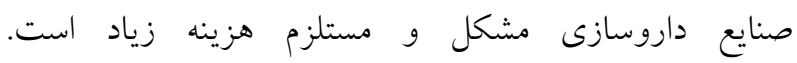

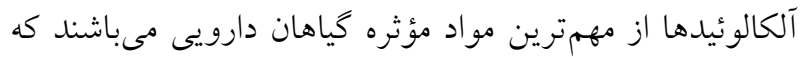

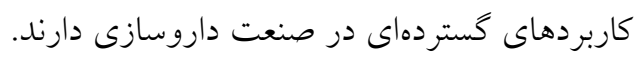

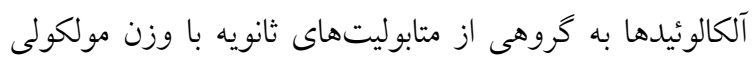

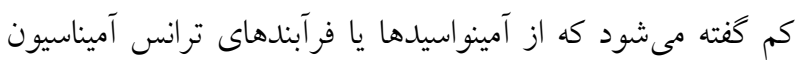

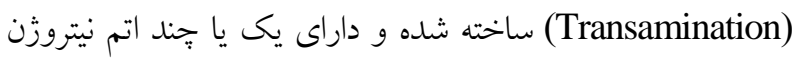
در ساختار هتروسيكليك خود هستند و غالباً به عنوان تركيبات

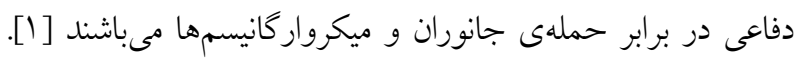

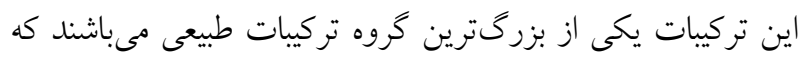

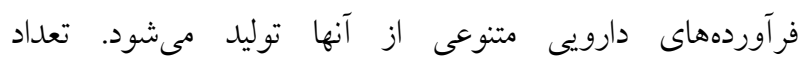

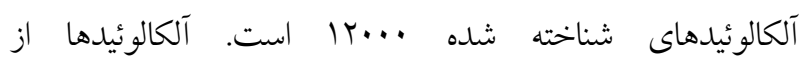

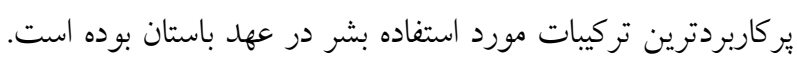

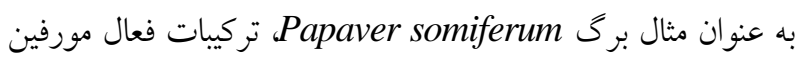

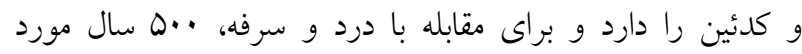

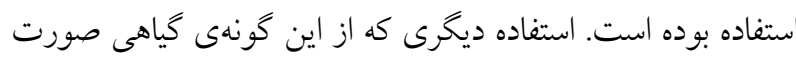

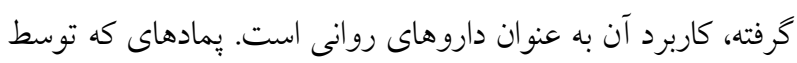

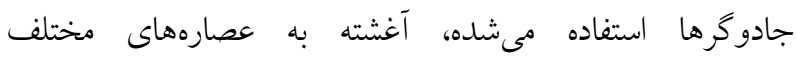
Solanaceae

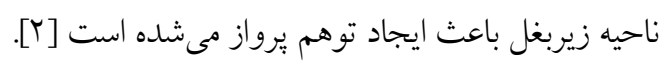

\section{كروهبندى آلكالوئيدها}

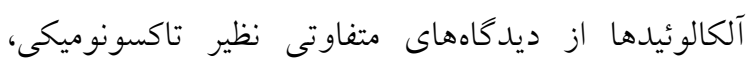

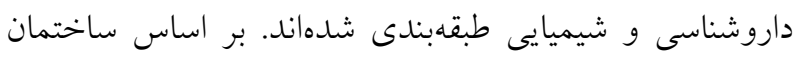

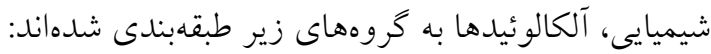


همجنين جشم، قلب، مثانه و دستخاه گوارش ممانعت مى كند

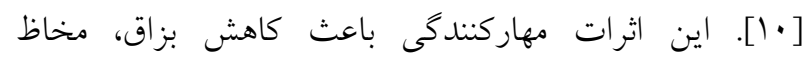

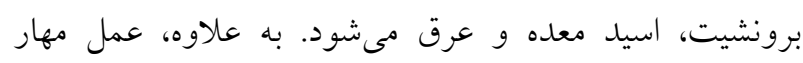

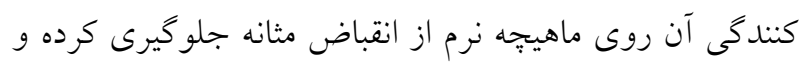
باعث كاهش حركات دودى رودهه مىشود [ ·1].

\section{ويزّكى هاى فيزيكوشيميايى ترويان آلكالوئيدها الف) اسكويولامين}

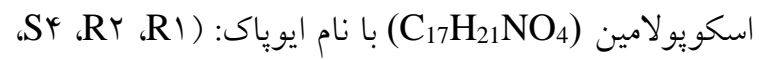

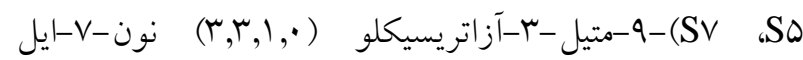
-r-SY)

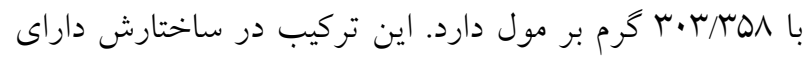

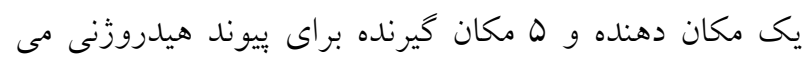

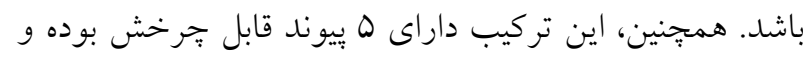

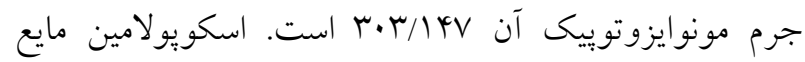

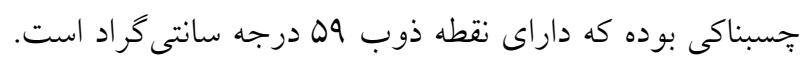

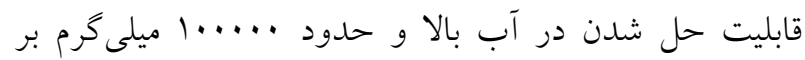

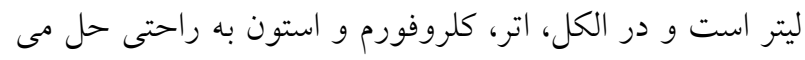

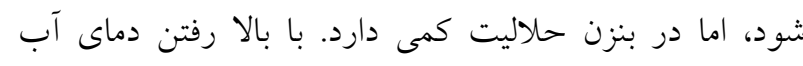

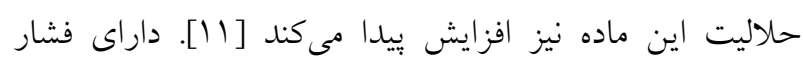

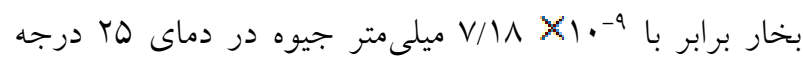

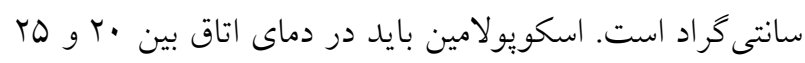

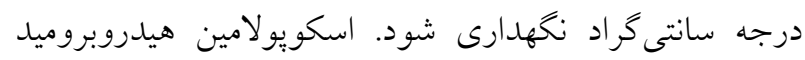

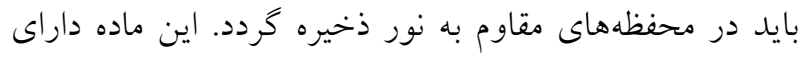
ثابت حلاليت

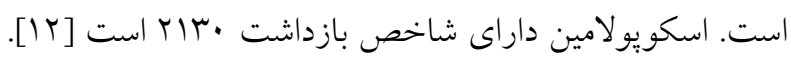

ب) آترويين آترويين آتروين

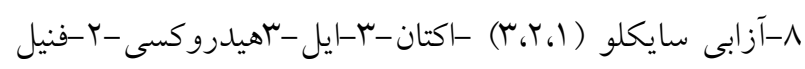

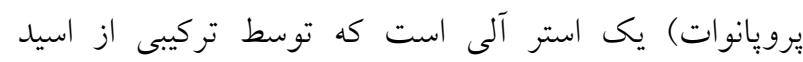

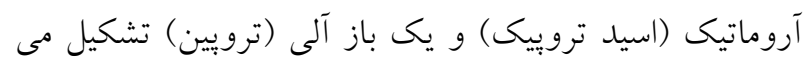

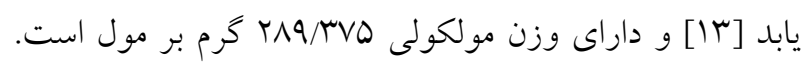

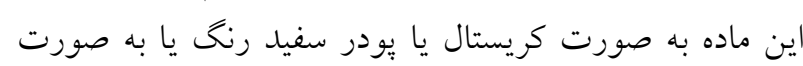

جذب سروتونين، نورايى نفرين و دويامين مىشود. كو كائين در

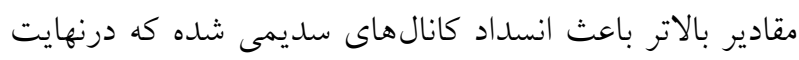
سبب از كار افتادن قلب مىشود. استعمال بيش از حد كو كائين

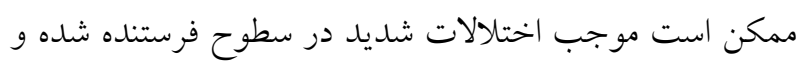

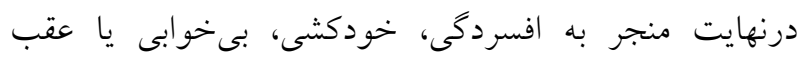

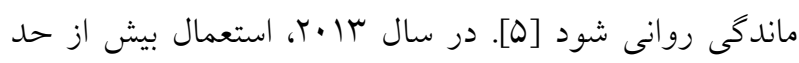

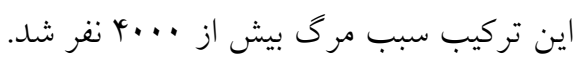

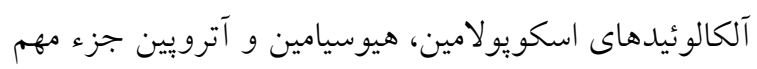

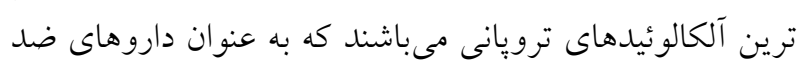
كوليك و اسياسموليتيكى در دستخاه گوارش و دفع ادرار مورد

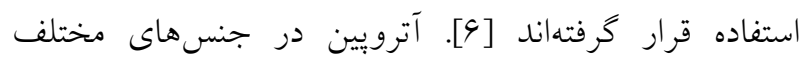

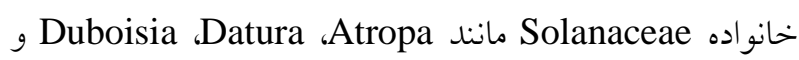
يافت مىشود و آلكالوئيد اصلى در ريشههاى Hyoscyamus كياه شابيزى Atropa belladonna است. اين تركيب بيشتر به ونه خاطر اثرات آنتى كولينرزيك (Anti-cholinergic) كه روكي

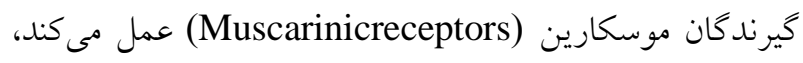

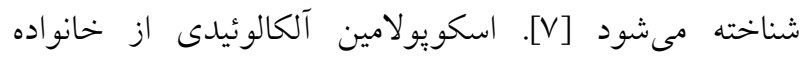

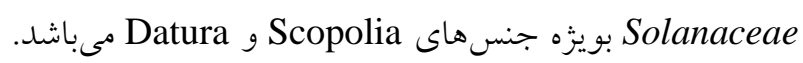

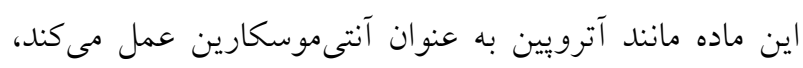
اما تأثير بيشترى روى سيستم عصب مركزى دارد. اين متابوليت

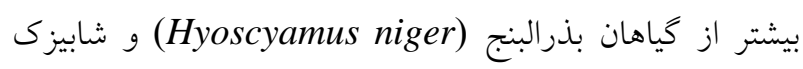
تهيه مىشود [^]. به دليل اينكه از (Atropa belladonna) نظر ساختارى بسيار شبيه به استيل كولين مى فياشد،

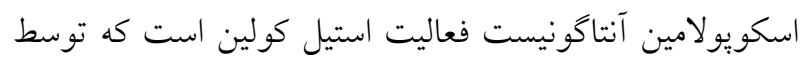

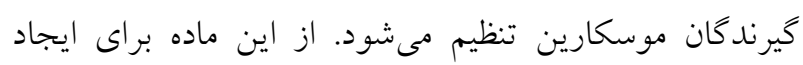

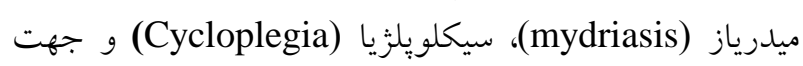

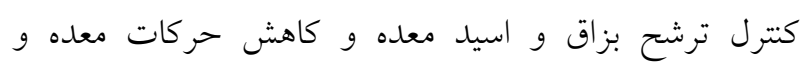

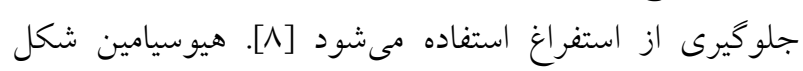

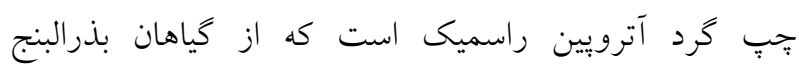
Atropa belladonna يا شابيزى Hyoscyamus niger

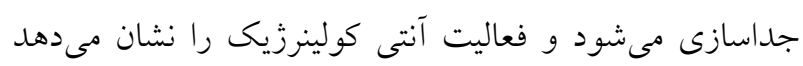

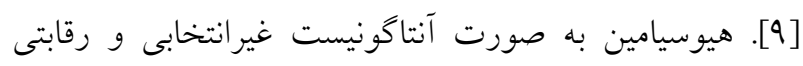

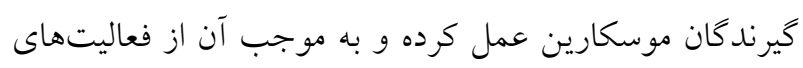

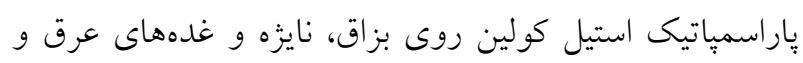




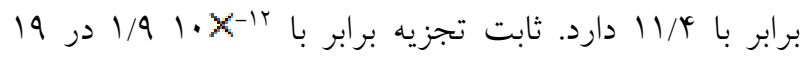
درجه سانتى گراد دارد [ [بr]

كياهان داراى آلكالوئيدهاى ترويانى اسكويولامين، آترويين و هيوسيامين هماند ديخر متابوليتهاى ثانويه كياهى، آلكالوئيدهاى

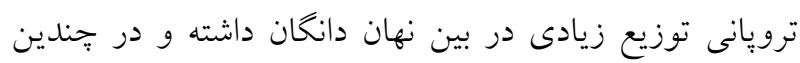

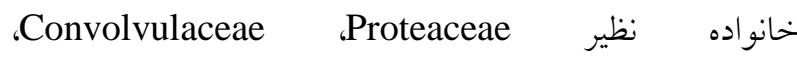
‘Rhizophoraceae ‘Euphorbiaceae ‘Brassicaceae Erythroxylaceae و كزارش شدهاند، كه Solanaceae بسيارى از اين خانوادهها از نظر تاكسونومى فاصله زيادى از

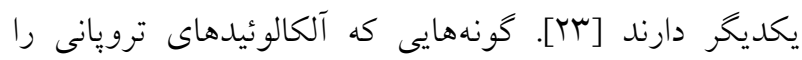

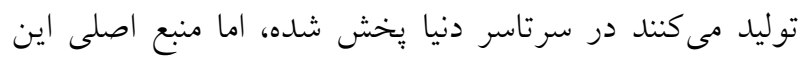

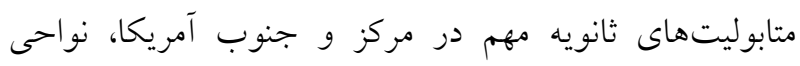

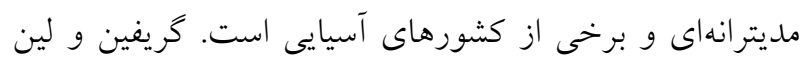

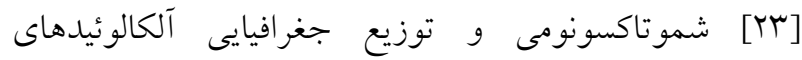
Solanaceae ترويانى را مطالعه و كزارش كردند كه خانو

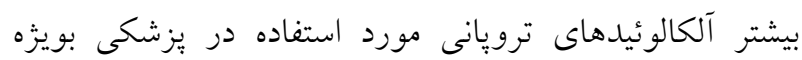

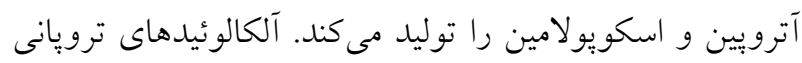

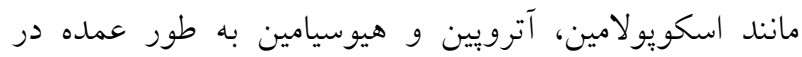
جنس هاى Duboisia، Atropa Hyoscyamus ،Datura ، يافت مىشوند. اسكويولامين در مقادير بسيار زياد Scopolia

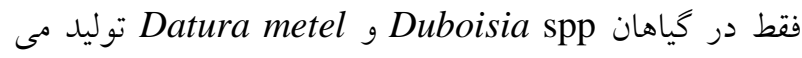
شود. منبع اصلى ماده خام براى توليد آلكالوئيدهاى ترويانى در ور

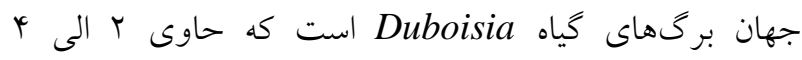

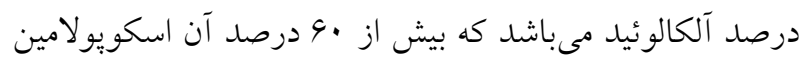
و •r درصد آن هيوسيامين است [9].

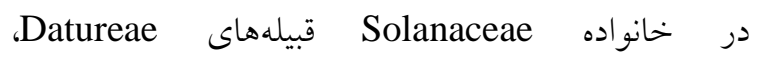
،Hyoscyameae Solaneae Solandreae Salpiglossidea Nicandreae ،Anthocercideae جنس هاى توليد كننده اين آلكالوئيدهاى ترويانى مهم هستند.

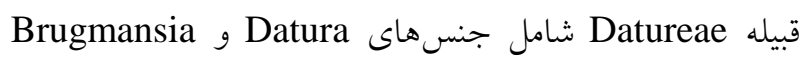
است كه گونههاى علفى و درختى را تشكيل مىدهند. در

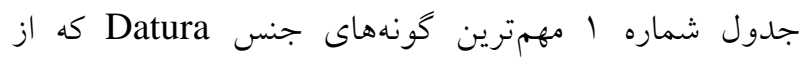

ماده ابريشم نما، با ساختار جهارضلعى ديده مىشود [14].

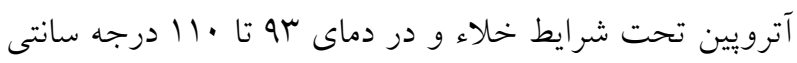

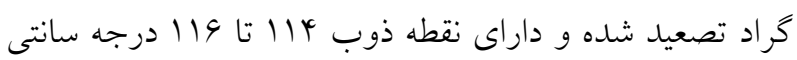

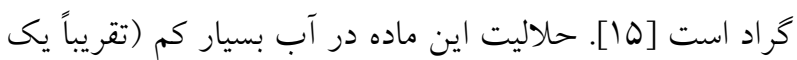

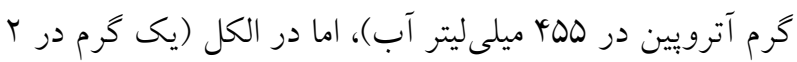

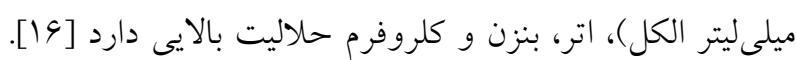

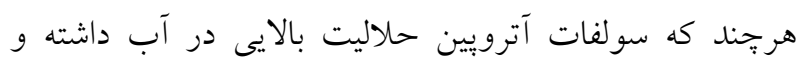

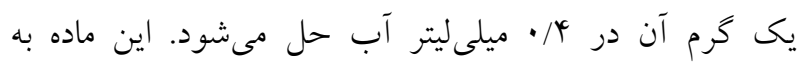
شدت حساس به نور و حرارت بوده و در حضور نور غيرفعال

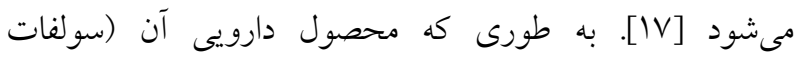

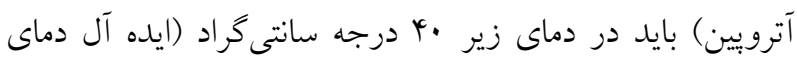

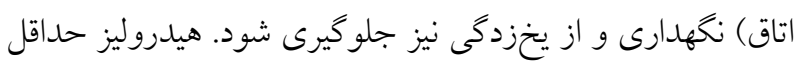

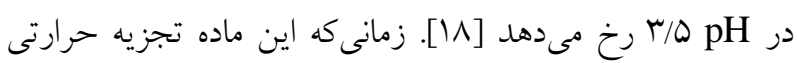

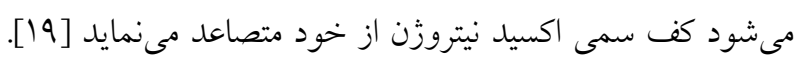

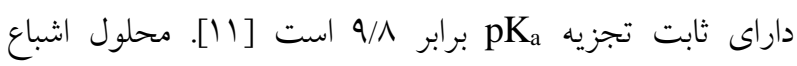

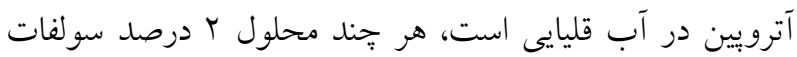

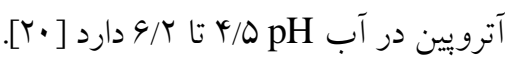

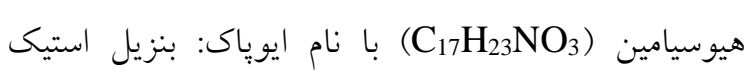

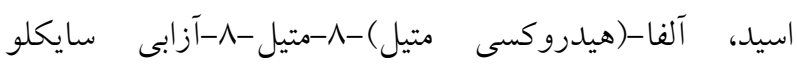

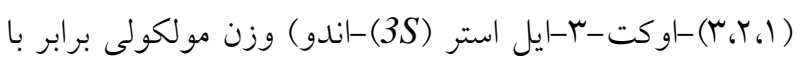

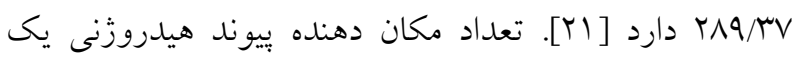

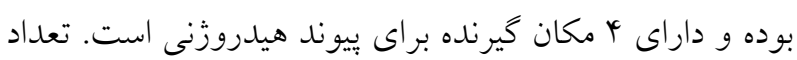

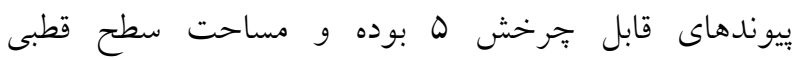

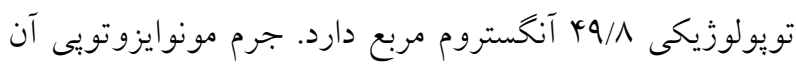


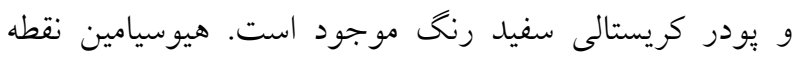

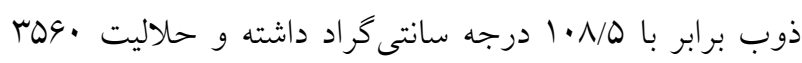

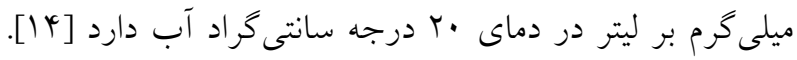

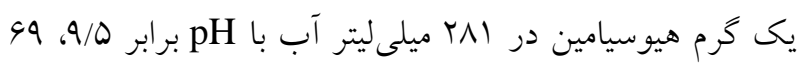

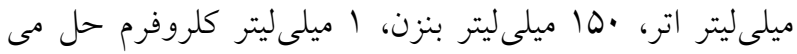

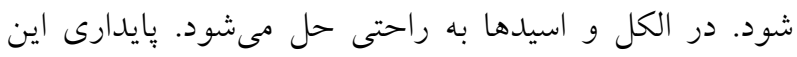
تركيب تحت تأثير نور و حرارت قرار مي كيرد و و ثابت 
يافت مىشود. اين آنزيم در ريشههاى جوان ساير كياهان

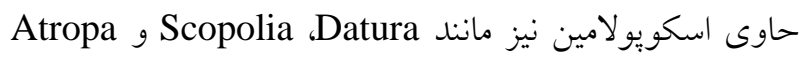

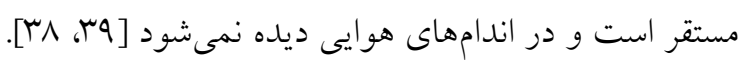

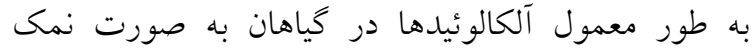

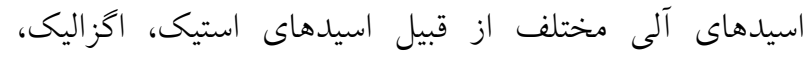

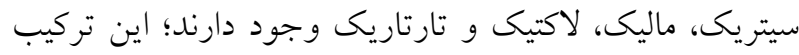

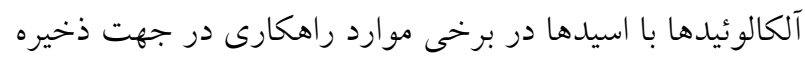

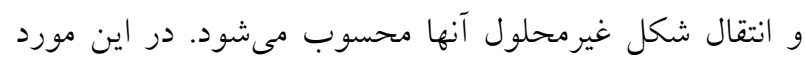

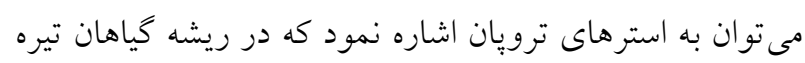
سولاناسه تشكيل مىشوند و سعبس به قسمتهاى هوايى گياه

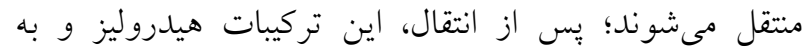

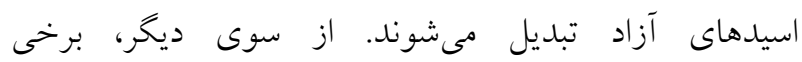

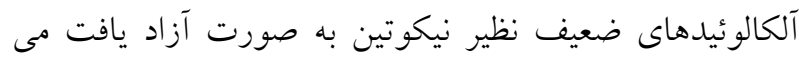

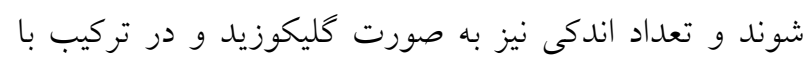

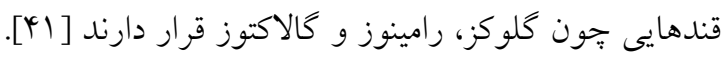

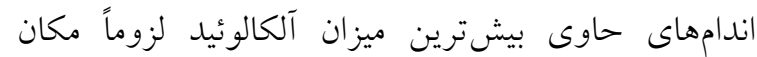
بيوسنتز اين تركيبات نيستند. بدين دليل در برخى كياهان انتقال

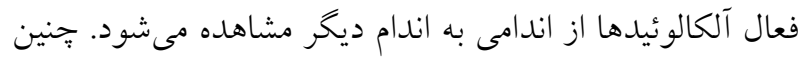

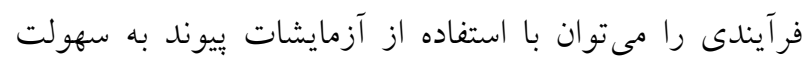

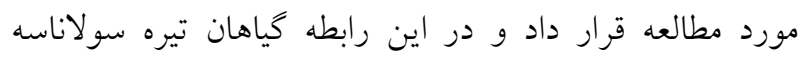

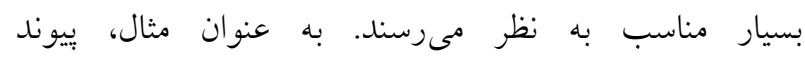

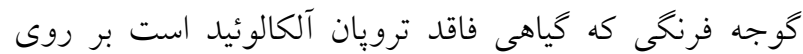
ريشه شابيزى كه يك كونه مولد اين تركيبات به شمار مىرود،

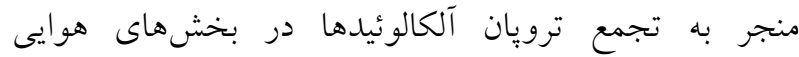

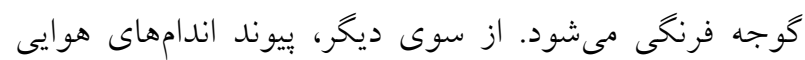

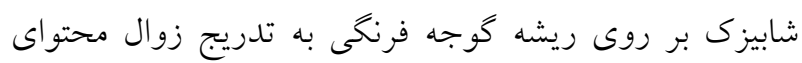

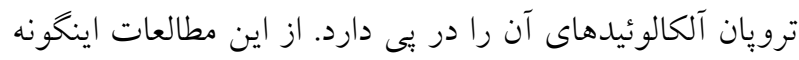

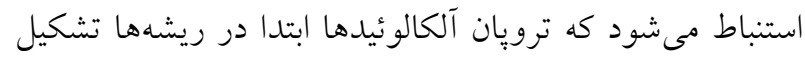

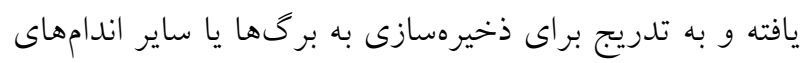

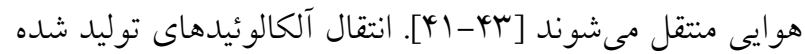

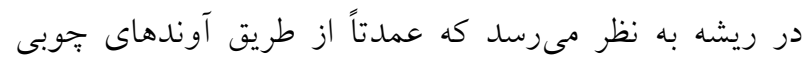

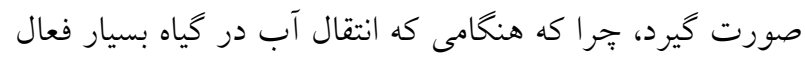

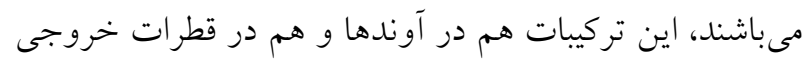
از نوك بركها قابل تشخيص هستند.
كَاهان توليد كننده آلكالوئيدهاى ترويانى مىباشد، فهرست شده

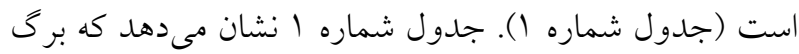

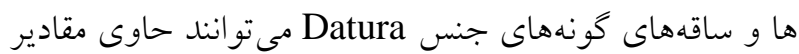
مشابه يا بالاى آلكالوئيدهاى ترويانى در مقايسه با بذر و كائل

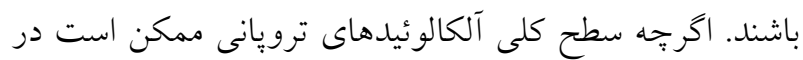

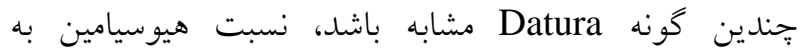

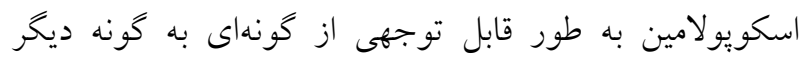

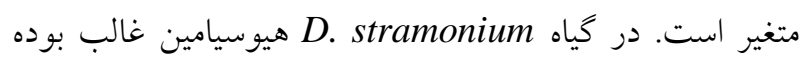

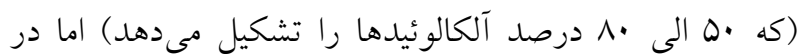

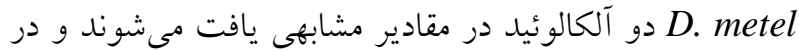
D. ferox است در جمعيتهاى مختلف گياهان حاوى اين آلكالوئيدهاى

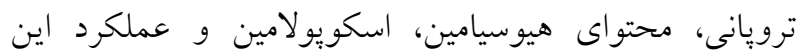

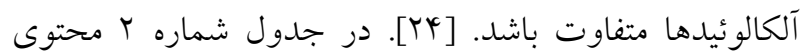

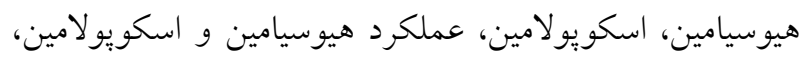
نسبت اسكويولامين به هيوسيامين در جمعيتهاى مختلف كياه بذرالبنج Higer ni آورده شده است.

سنتز، انتقال و ذخيره آلكالوئيدهاى ترويانى در گياهان مكان بيوستزى آلكالوئيدهاى ترويانى دايره محيطيه در ريشههاى جوان و ريشههايى كه فاقد رشد ثانويه هستند

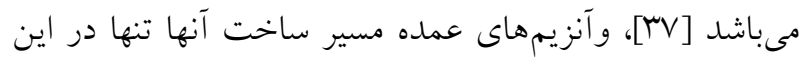

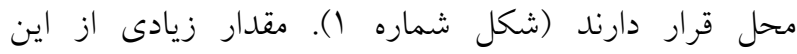

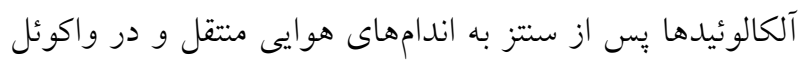
بافتهاى مختلف متمركز مىشوند. نخستين مرحله بيوسنتز

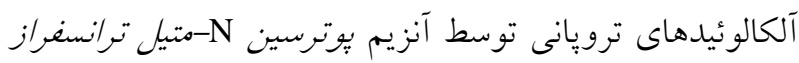
كاتاليز مىشود. تبديل هيوسيامين به اسكويولامين از (PMT) طريق ماده واسطه 9- بتا - هيدروكسى هيوسيامين صورت مى آنى

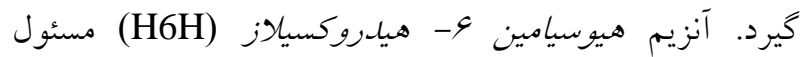

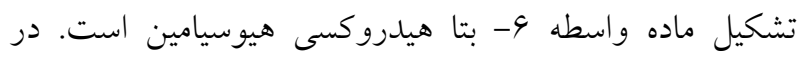

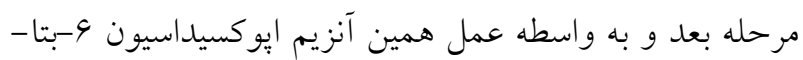

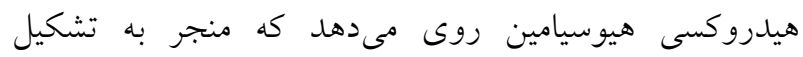

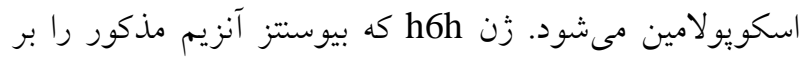
عهده دارد، تنها در كونهاى سولاناسه توليدكننده اسكويولامين 
جدول شماره ا - گياهان حاوى آلكالوئيدهاى ترويانى اسكويولامين و هيوسيامين در گونهاى مختلف جنس Datura

\begin{tabular}{|c|c|c|c|c|}
\hline منبع & توضيحات & نام علمى & نام انخليسى & رديف \\
\hline TQ & 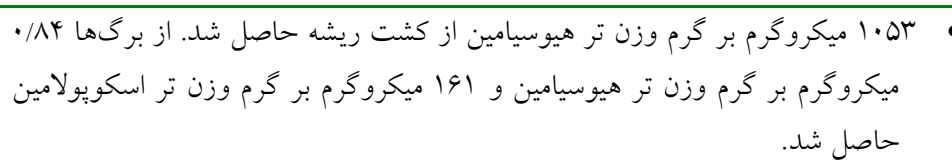 & - $\quad$ D. stramonium L. & Jimsonweed & 1 \\
\hline ra & 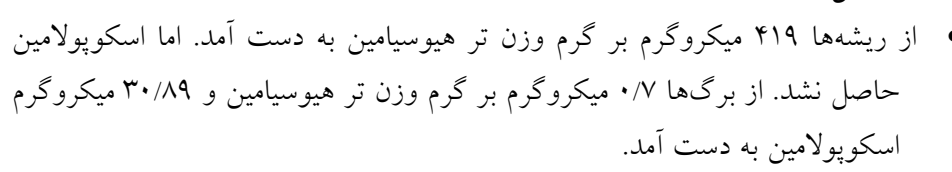 & - Datura quercifolia & $\begin{array}{l}\text { Chinese } \\
\text { thorn-apple }\end{array}$ & r \\
\hline TV & 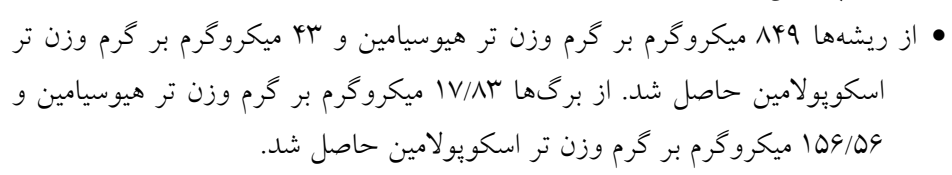 & Datura ferox & $\begin{array}{l}\text { Fierce } \\
\text { thornapple }\end{array}$ & r \\
\hline$r \wedge$ & 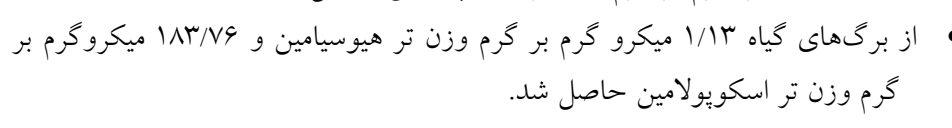 & Datura discolor & $\begin{array}{l}\text { Desert thorn- } \\
\text { apple }\end{array}$ & r \\
\hline rq & 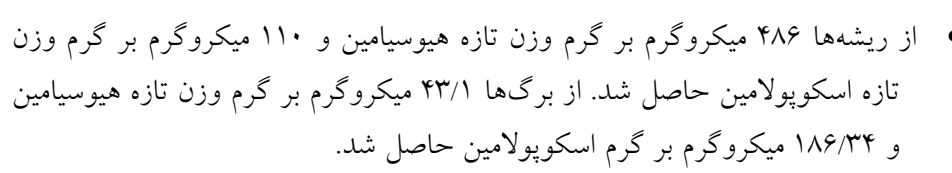 & Dature innoxia & Pricklyburr & 0 \\
\hline$r$. & 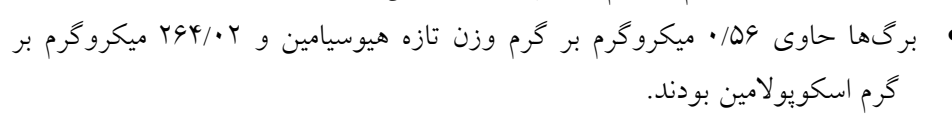 & $\begin{array}{l}\text { Datura } \\
\text { kymatocarpa }\end{array}$ & & 4 \\
\hline 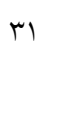 & 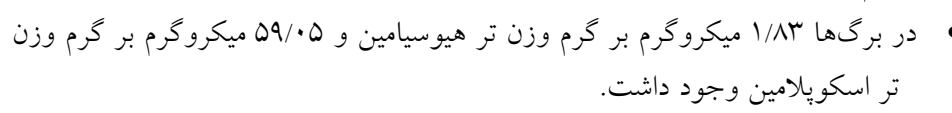 & - $\quad$ Datura pruinosa & Sacred datura & v \\
\hline r & 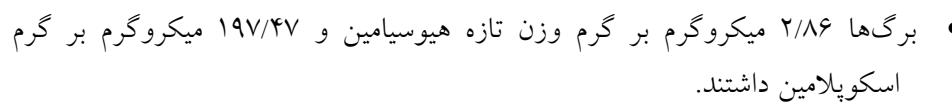 & - $\quad$ Datura reburra & & $\wedge$ \\
\hline س & 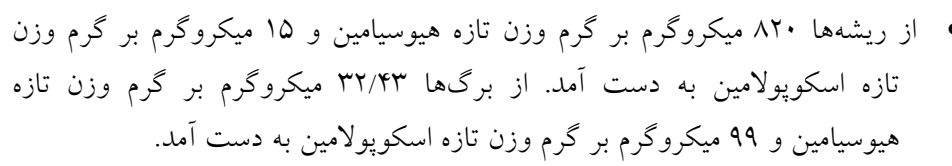 & Datura wrighti & & 9 \\
\hline me & 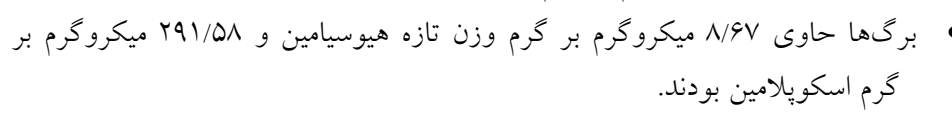 & Datura lanosa & & 1. \\
\hline ro & 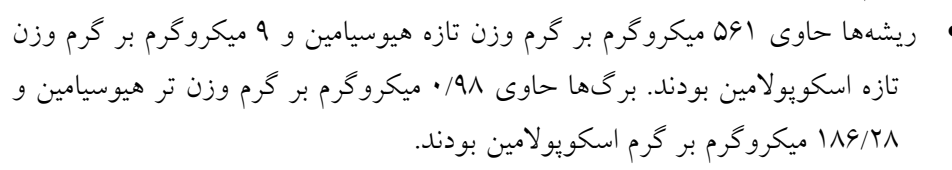 & Datura metel & $\begin{array}{l}\text { Devil's } \\
\text { trumpet }\end{array}$ & 11 \\
\hline re & 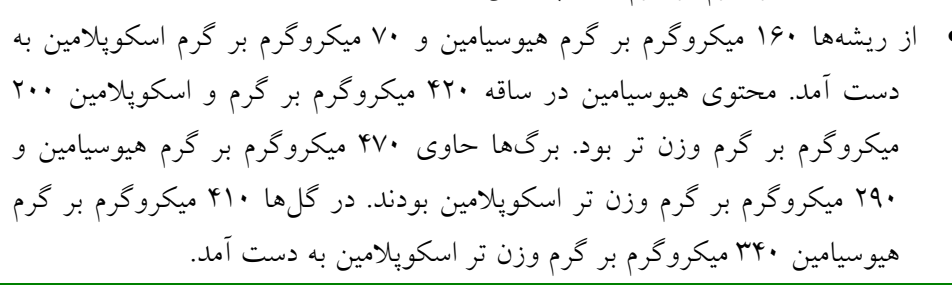 & $\begin{array}{c}\text { Datura } \\
\text { ceratocaula }\end{array}$ & $\begin{array}{l}\text { Brugmansia } \\
\text { ceratocaula }\end{array}$ & ir \\
\hline
\end{tabular}


نوهسى و همكاران

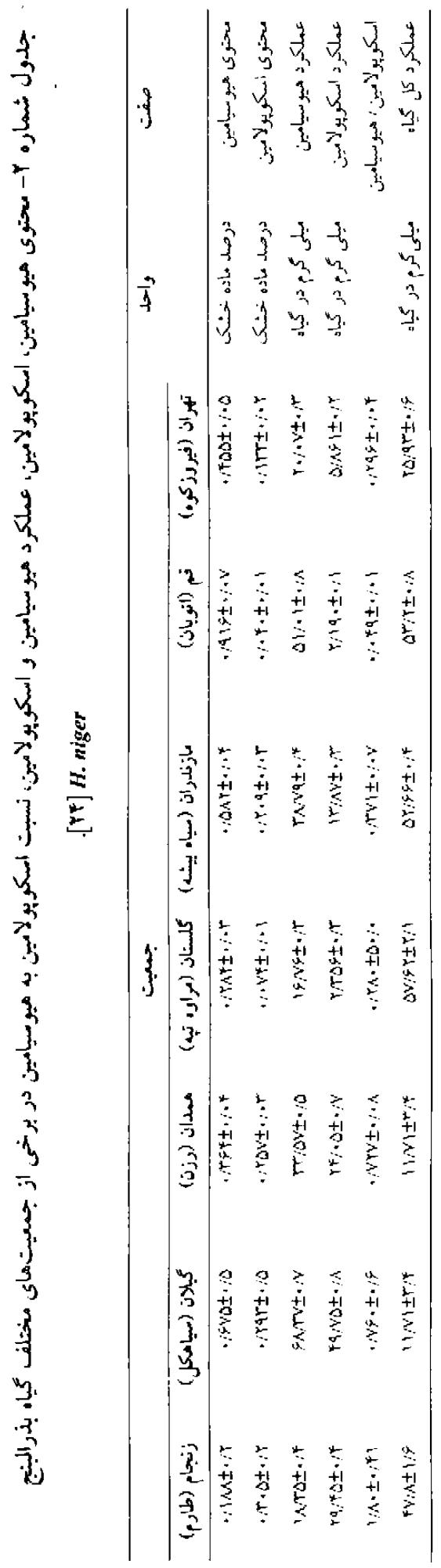

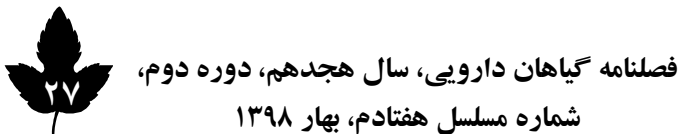




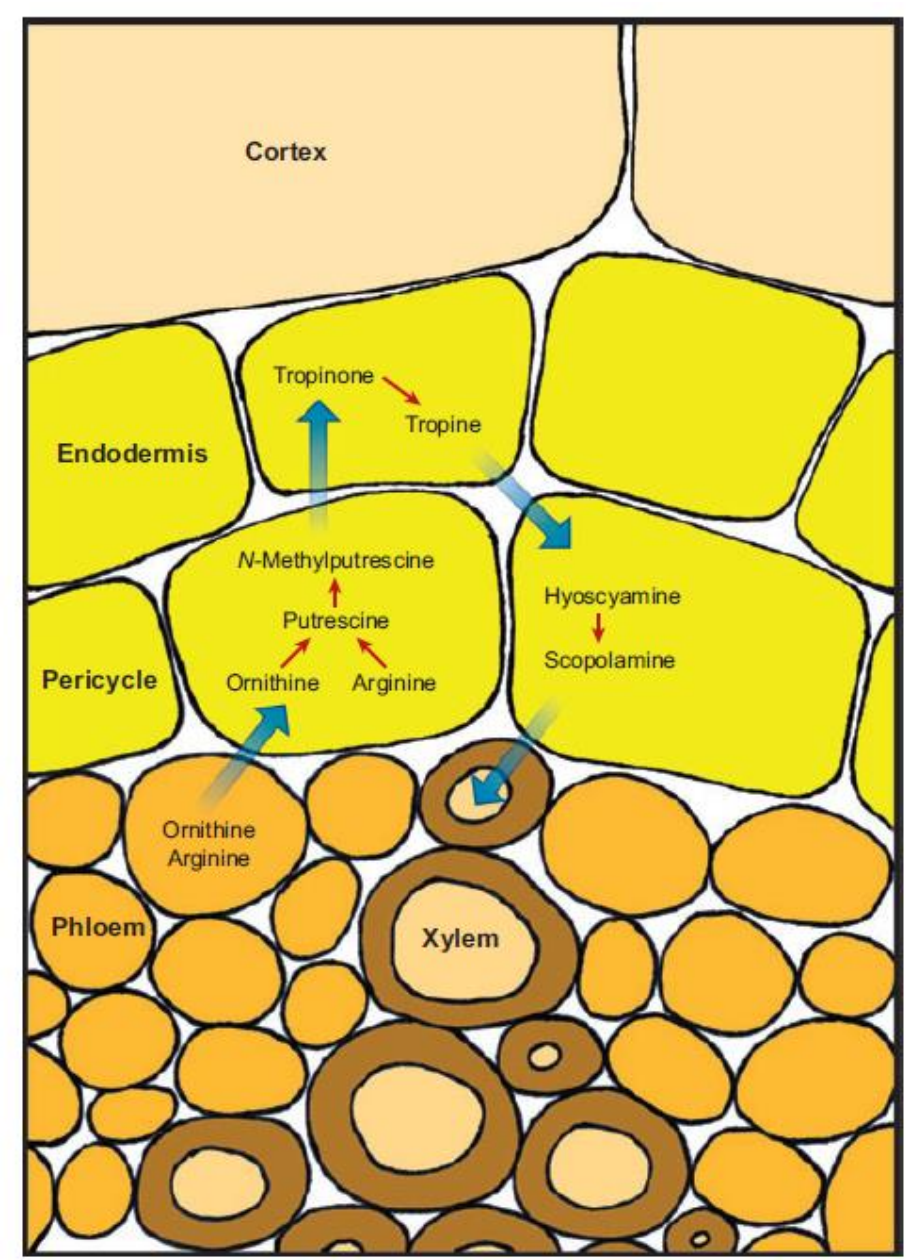

شكل شماره ا- بيوستز و تبديل هيوسيامين به اسكويولامين با حضور آنزيم PMT و H6H در دايره محيطيه ريشه و انتقال آن به آوند جوبى [•

حركت به هم مىخورد، وستيبول سيكنالى از طريق اعصاب به

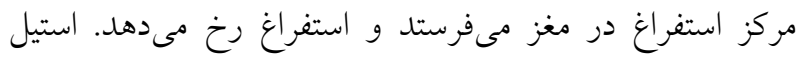

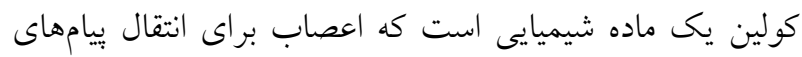

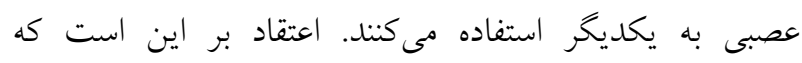

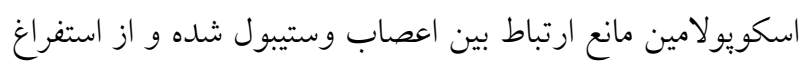

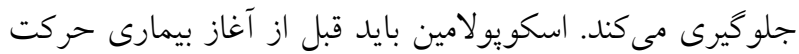
مصرف شود. ميل تركيبى اسكويولامين جهت اتصال به گيرنده

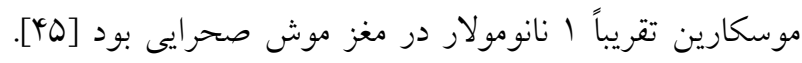

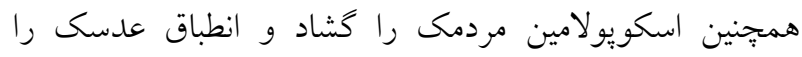

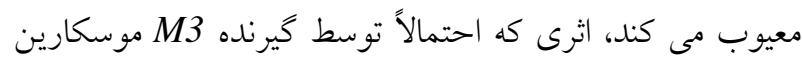

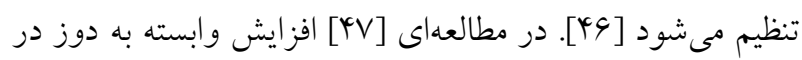

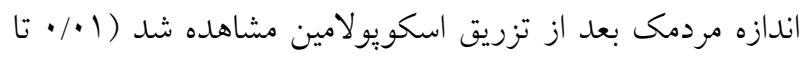

ارزش دارويى و خواص فارماكولوزيكى و مكانيسم اثر دارويى آلكالوئيدهاى ترويانى اسكويولامين يك آنتاكونيست موسكارين (مادهاى كه ميل اتصال بالايى به گيرندهاى موسكارينى داشته اما فعاليت درونى ندارد). مشابه با انتقال دهنده عصبى استيل كولين است و

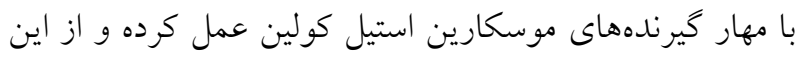

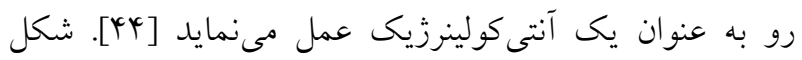

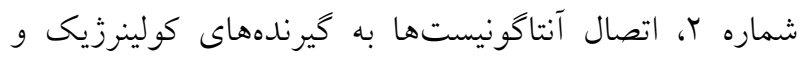
ممانعت از اتصال استيل كولين را نشان مىدهد.

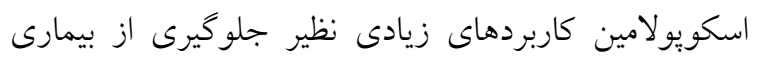

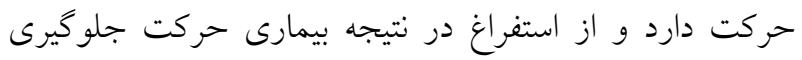

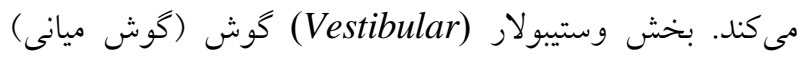
براى تعادل بسيار مهم است. وقتى تعادل شخصى در نتئيد 
نوهسى و همكاران

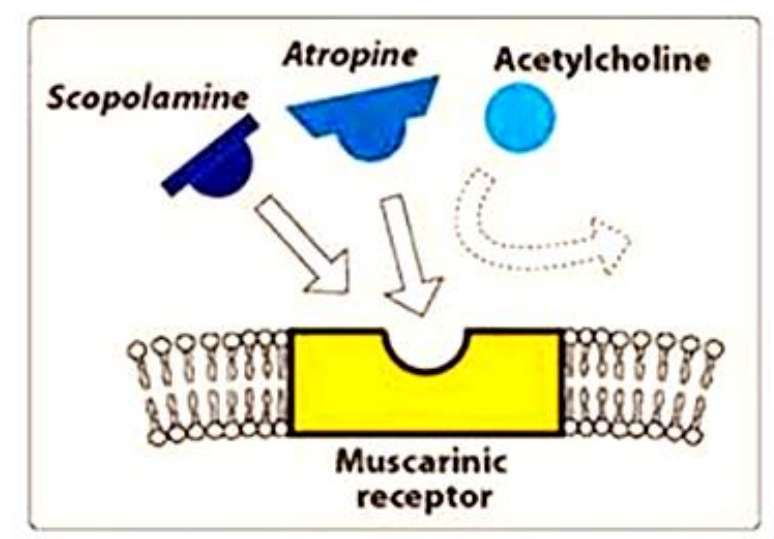

شكل شماره Y- اتصال آنتاكونيستهاى آترويين يا اسكويولامين مانع از اتصال استيل كولين مىشود.

با اين حال، آن به عنوان ماده آنتى موسكارين مصطلح شده زيرا

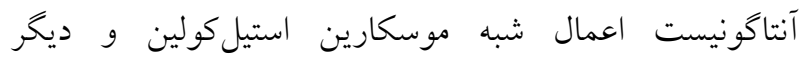

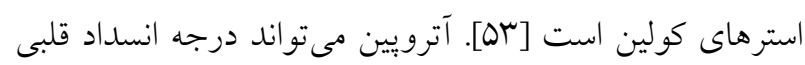

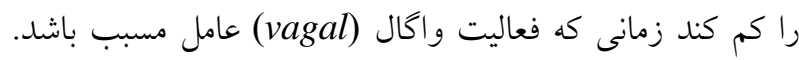

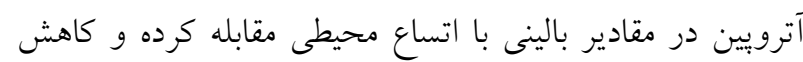

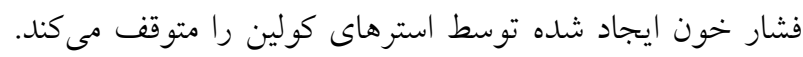

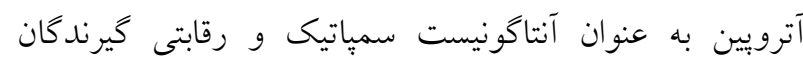

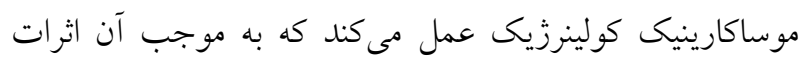

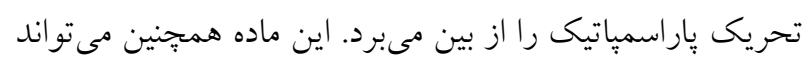

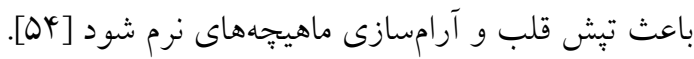

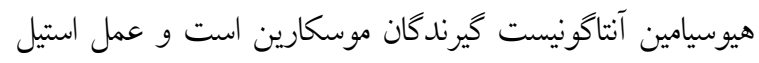

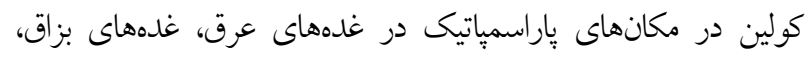

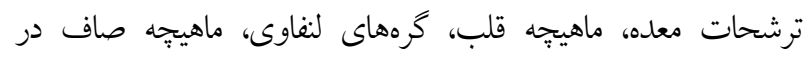

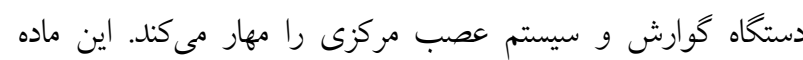

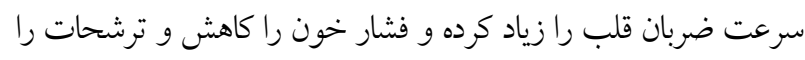

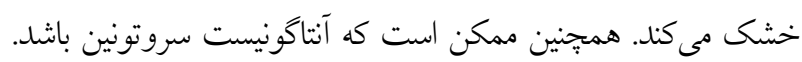

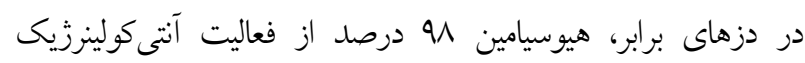
آترويين را داراست [هD]. هيوسيامين از اختصاصيت اعمال استيل كولين درين

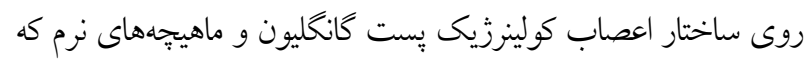

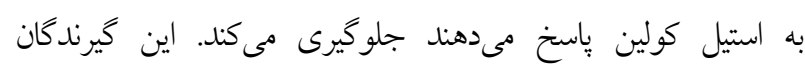
كولينزيك سطحى در سلولهاى افكتور اتونوميك ماهيجه نرم، ماهيجها

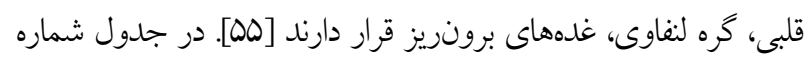

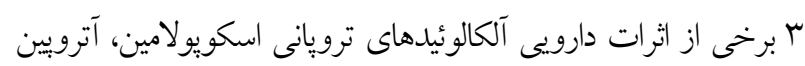

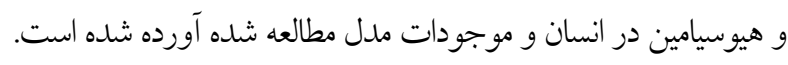

1/ • ميلى گرم بر كيلوكرم). به علاوه، اسكويولامين بزاق را

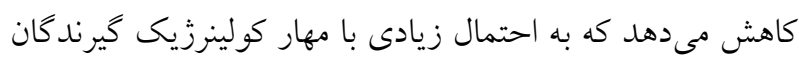

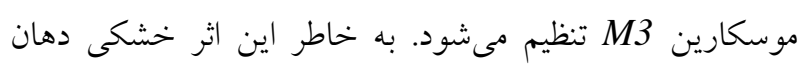

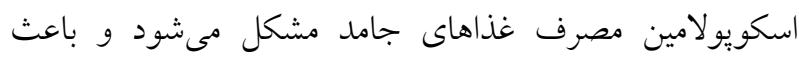
كاهش مصرف غذا مىشود [YYN]

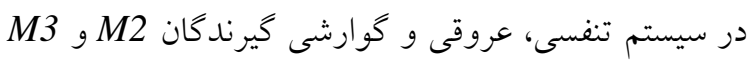
به نظر مىرسد كه انقباض ماهيجه صاف را كتترل مى كنند.

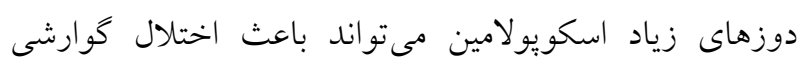

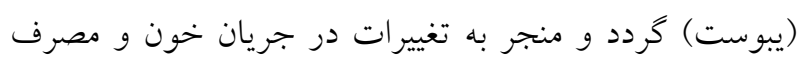

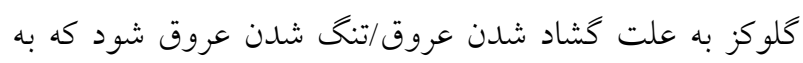

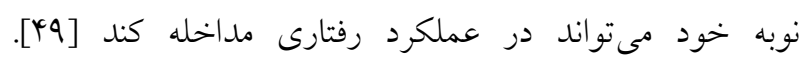

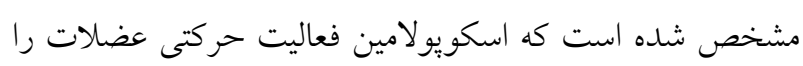

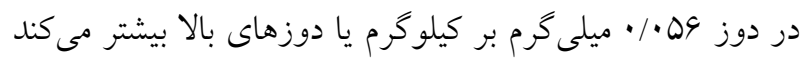

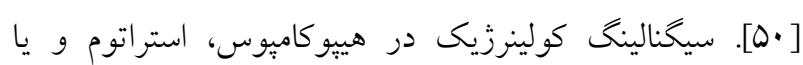

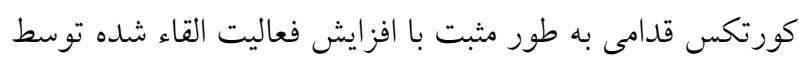

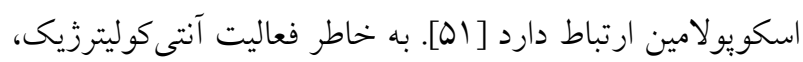

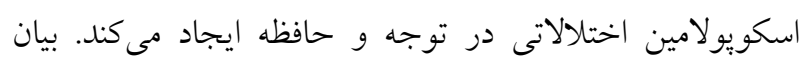

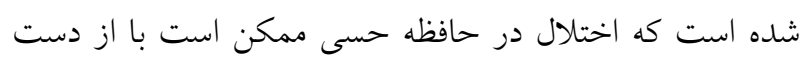
دادن گيرندكان موسكارين در سيستم عصب مركزى و و با انتقال

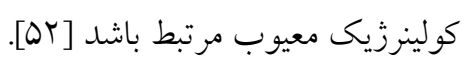

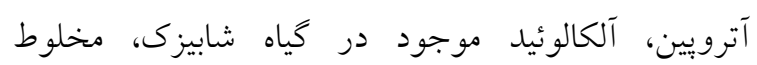

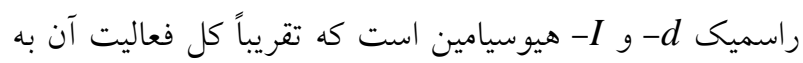

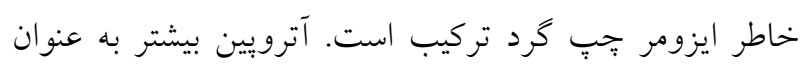

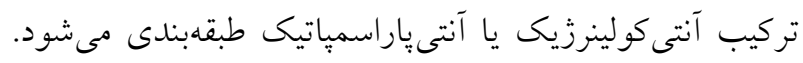


جدول شماره س- برخى از اثرات دارويى آلكالوئيدهاى ترويانى اسكويولامين، آترويين و هيوسيامين در انسان و موجودات مدل مطالعه شده

\begin{tabular}{|c|c|c|c|c|}
\hline منبع & نتيجه & آنومايش & اثر دارويى & نوع تر كيب \\
\hline$\Delta G$ & - آترويين به طور كامل از فراموشى القاء شده توسط شرايط اكسيزن كم و محتوى & حيوانى & ضدفراموشى & \\
\hline$\Delta V$ & پِاسخ بالينى خوبى با افزايش قدرت دست، محدوده حركت و ترموگرافى كمّى به دست آمد. & انسان & $\begin{array}{l}\text { pulmonary بيمارى } \\
\text { hypertrophic } \\
\text { osteoarthropathy }\end{array}$ & \\
\hline$\Delta \wedge$ & تأثير آترويين به من من موشى موش توسط ماده متوكسى فلوران با استفاده از آترويين زياد شد. & 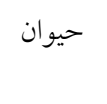 & بى هوشى & آترويين \\
\hline Q9 & 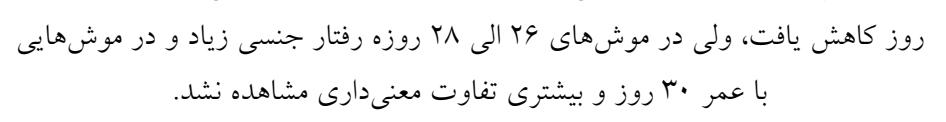 & 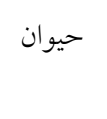 & رفتار تحريك جنسى & \\
\hline G. & 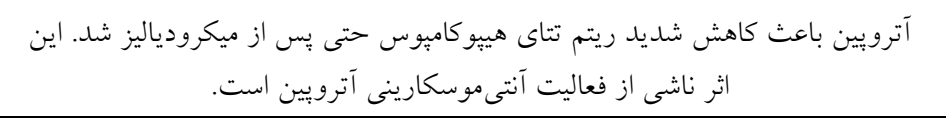 & حيوانى & ريتم تتاى هيبو كاميوس & \\
\hline 91 & 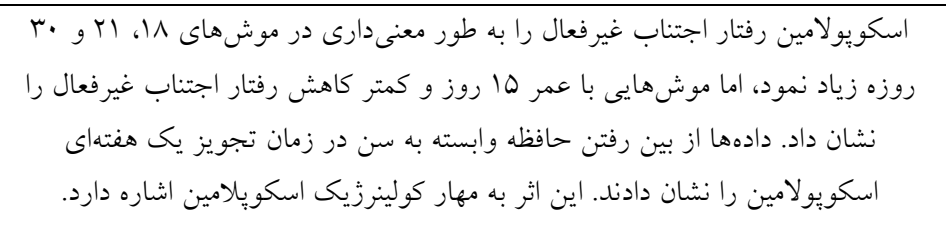 & حيوان & رفتار اجتناب غيرفعال & \\
\hline GY & اسكويو لامين باعث كاهش عملكرد يردازش اطلاعات شد. & انسان & عملكرد يردازش اطلاعات & \\
\hline $9 r$ & 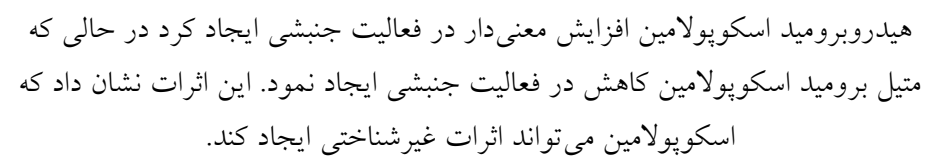 & حيوان & فعاليت جنشى & اسكويو لامين \\
\hline s4 & كاهش تيزفهمى بصرى، كُشاد شدن مردمك و عدم ياسخ به نور از عوارض جانبى اسكويولامين بود. & 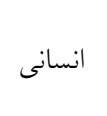 & مطالعه اثرات جانبى & \\
\hline 90 & 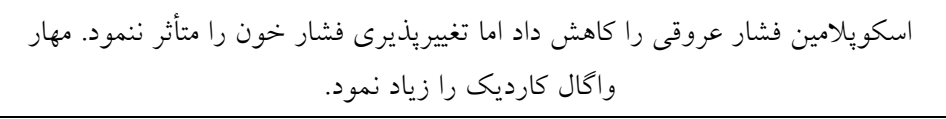 & 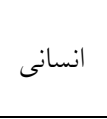 & $\begin{array}{l}\text { كنترل خودايمنى قلبى عروقى } \\
\text { عروقى }\end{array}$ & \\
\hline 94 & 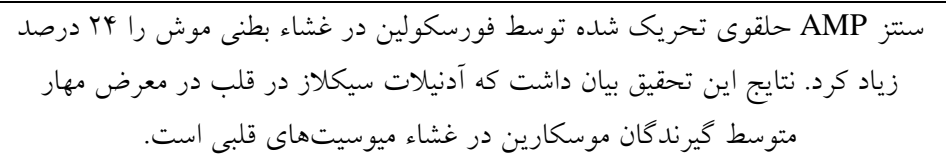 & حيوانى & مهار عمل كيرندكان & هيوسيامين \\
\hline $9 V$ & عمل ضدتيش نامنظم قلب هيوسيامين ثابت شد كه به ويز كى هاى آنتى كولينرزيك اين & حيوانى & تش نامنظم قلب & \\
\hline
\end{tabular}

يوترسين را توليد مى كند. البته آرزنين هم با دكربوكسيله شدن

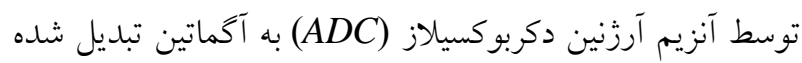

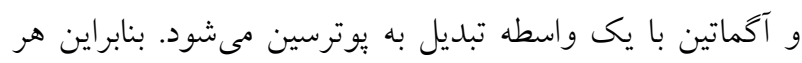
دو آمينواسيد مىتوانند مسير راشروع كنند [9N].

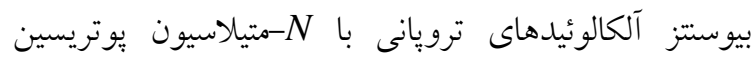
وابسته به S- آدنوزيل متيونين (SAM) توسط آنزيم يوتريسين

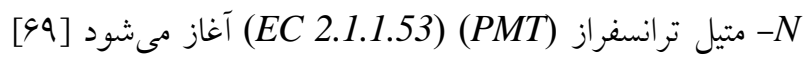

مسير بيوسنتزى آلكالوئيدهاى ترويانى اسكويولامين، هيوسيامين و آترويين مسير بيوستزى ترويان آلكالوئيدها در ابتداى مسير با مسير بيوسنتزى تركيبات كو كائين و كاليستزين مشترك است. به طور

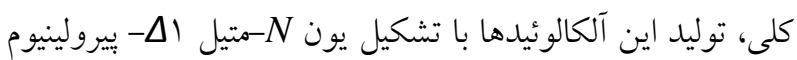

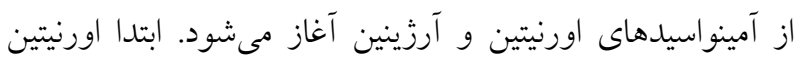
توسط آنزيم اورنيتين دكربوكسيلاز (ODC) دكربو كسيله شده و و 
زودوترويين، نقطه اصلى انشعاب در بيوسنتز آلكالوئيدهاى

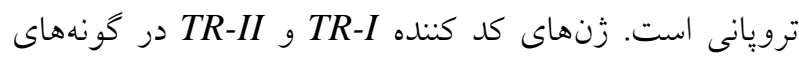
توليد كننده آلكالوئيد ترويينون ترنهاي كاني

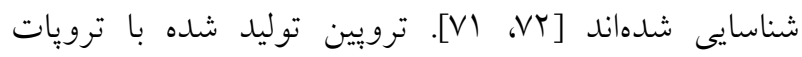

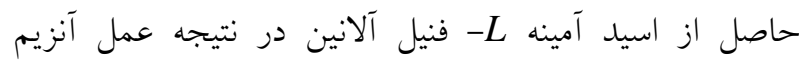

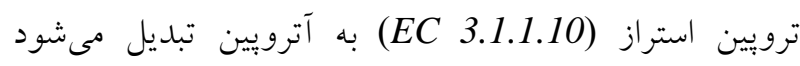

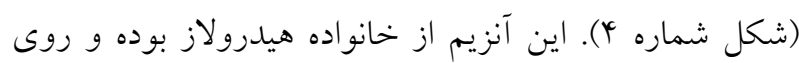

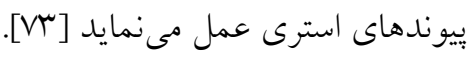
همجنين ترويين مىتواند با فنيل لاكتاتيل كوآنزيم حاصل از متابوليسم فنيل آلانين تركيب شود و ايجاد ليتورين نمايد [VY -VY]. سبس ليتورين تبديل به هيوسيامين مىشود.

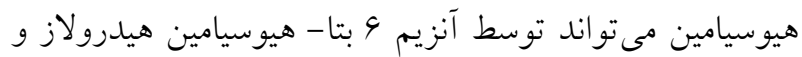

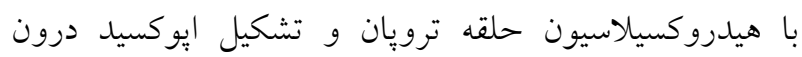

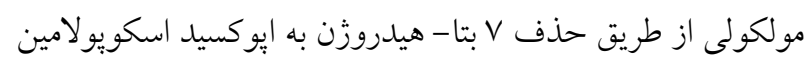

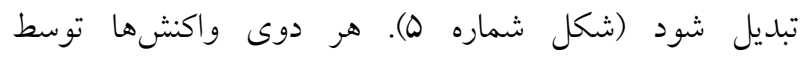
دىاكسيزناز وابسته به r اخزو كلوتارات، 9 بتا-هيدروكسيلاز

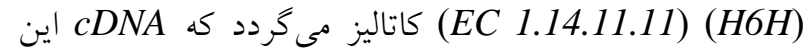

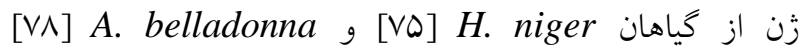
جداسازى شده است. فقط خياهان توليد كننده اسكويولامين

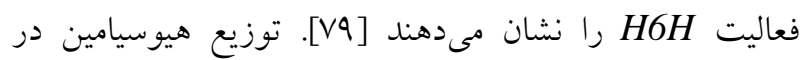

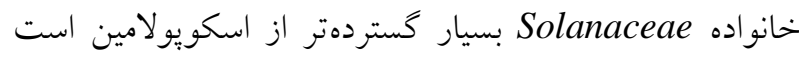
كه بيان كننده اين مىباشد فقط لينهاى فيلوزنتيكى معينى زن كد كننده H6H را اكتساب كردهاند (شكل شماره ه). اسكويولامين، با اكسيداسيون مستقيم هيوسيامين بدون

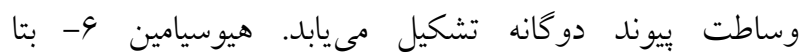
هيدروكسيلاز (H6H) يك دى واكسيزناز وابسته به اكزو كلوتارات

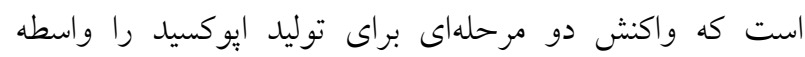

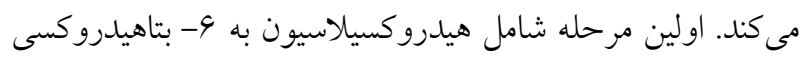

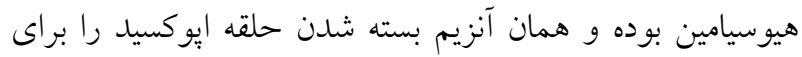

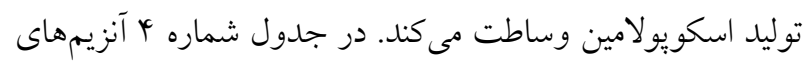

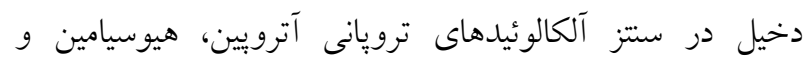

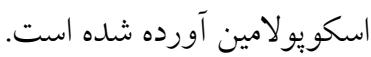

(شكل شماره ب)، كه cDNA آن از كياه شابيزى (Atropa belladonna) جداسازى شده است [V•]. N- N- متيل يوتريسين توسط دى آمين

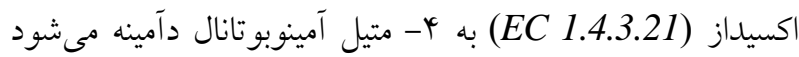
كه جهت تشكيل كاتيون فعال N-متيل-4ا-سيرولينيوم به طور خود به خودى حلقوى مىشود. تصور مىشود كه كاتيون N-Nمتيل - اله- ييرولينيوم با اسيد استواستيك براى ايجاد هيخرين

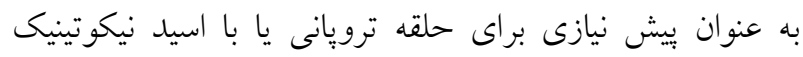
جهت تشكيل نيكوتين متراكم مى گردد (شكل شماره بَ).

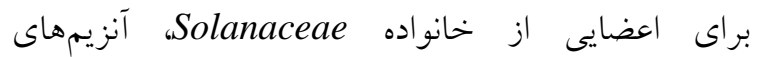

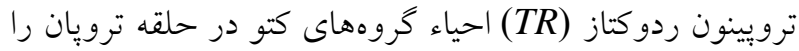

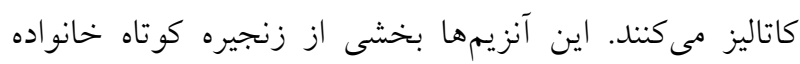

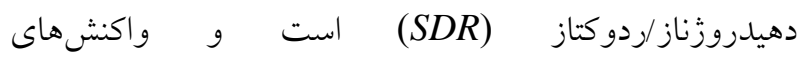
اكسيدوردو كتاز مونومريك وابسته به (H)(P)

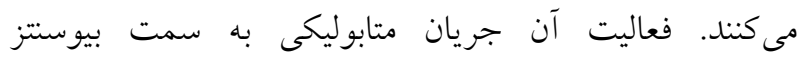

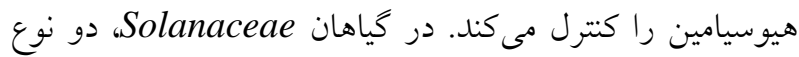
ترويينون ردوكتاز وجود دارند، ترويينون ردوكتاز I IRI) و

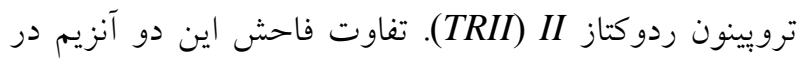

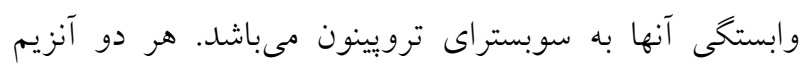

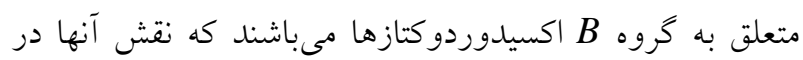

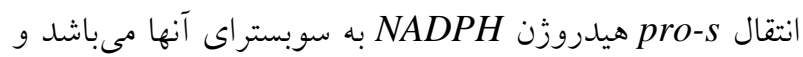
ميل تركيبى متفاوتى سنبت به ترويينون از خود نشان ميدوهند TR-II)

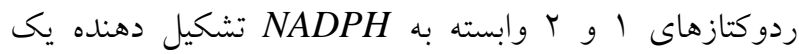

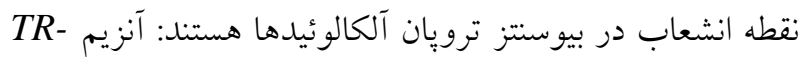

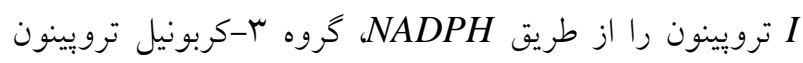

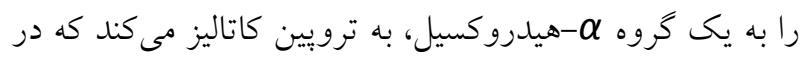

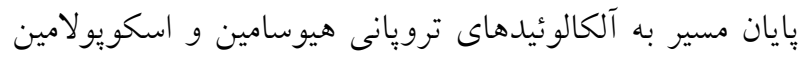

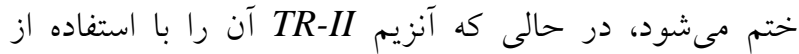
NADPH

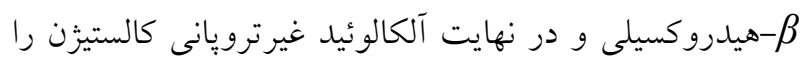

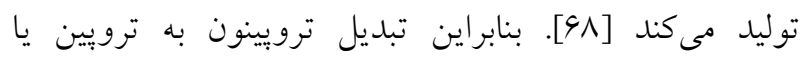




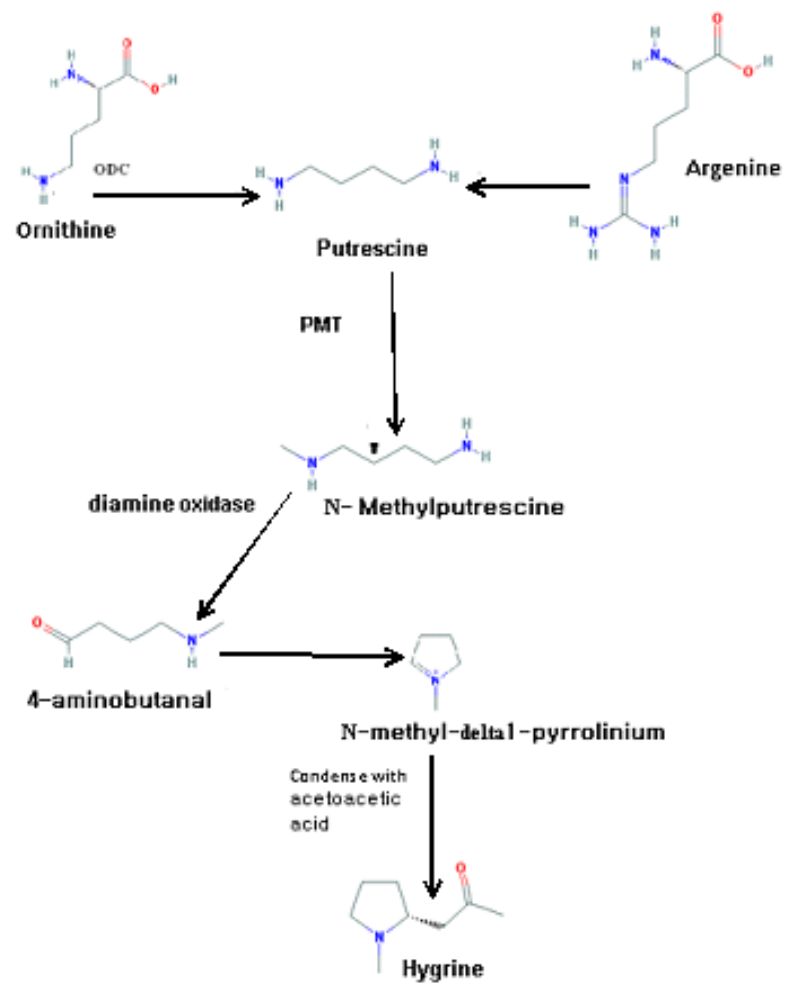

شكل شماره ب- تشكيل حلقه ترويانى لازم براى سنتز آلكالوئيدهاى ترويانى آترويين، هيوسيامين و اسكويولامين. تشكيل بوتريسين از اسيد آمينهاى

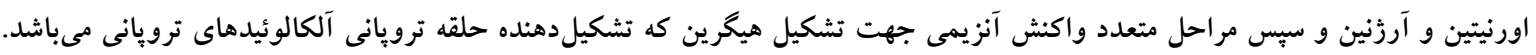

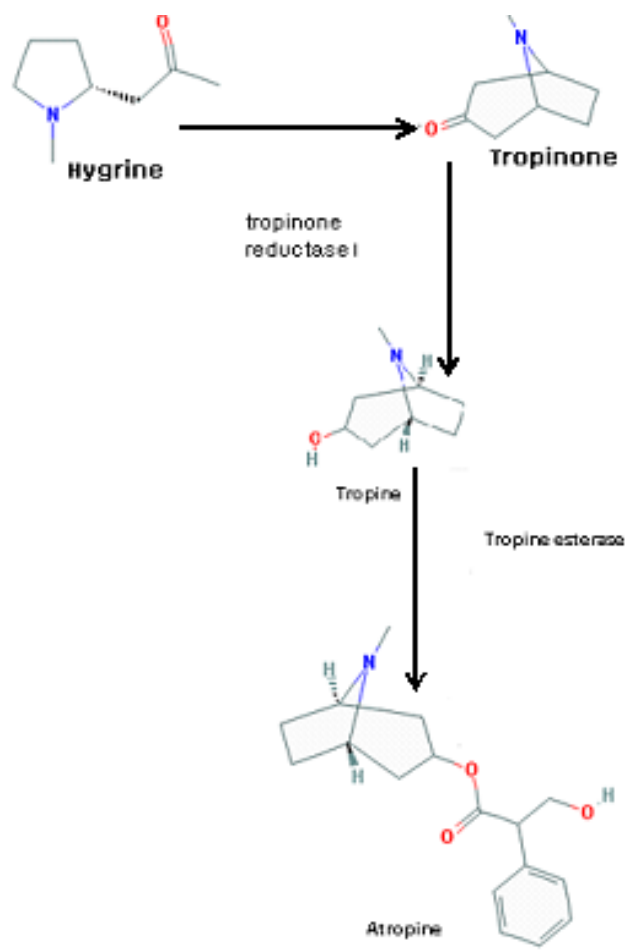

شكل شماره F- مسير بيوسنتز آلكالوئيد ترويان آترويين. ماده هيخرين توليد شده در اثر مكانيسم ناشناختهاى تبديل به ترويينون مىشود. ترويينون حاصل

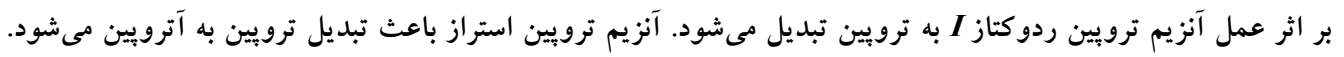


نوهسى و همكاران

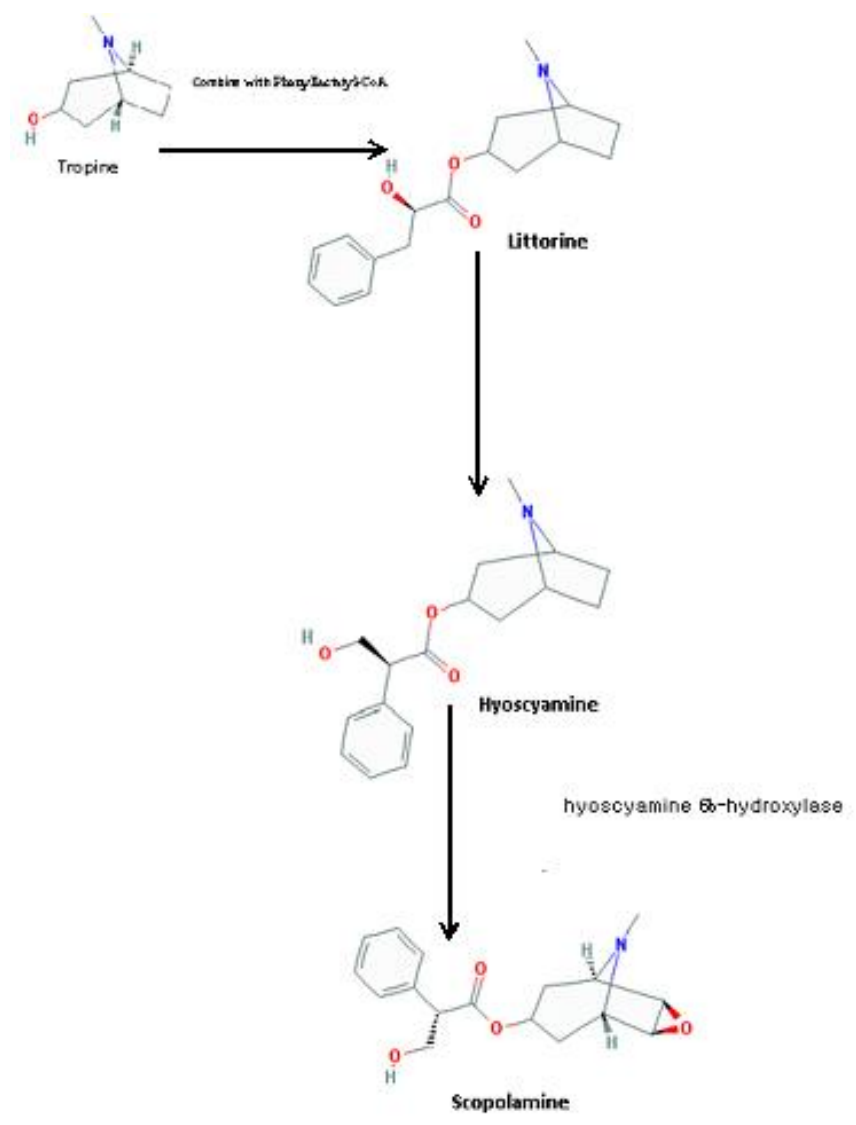

شكل شماره ه- مسير بيوستز دو آلكالوئيد ترويانى مهم: هيوسيامين و اسكويولامين

جدول شماره ץ- آنزيمهاى دخيل در مسير بيوسنتز آلكالوئيدهاى ترويانى اسكويولامين، آترويين و هيوسيامين

\begin{tabular}{|c|c|c|c|c|c|}
\hline 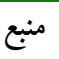 & دخيل در بيوسنتز آلكالوئيد & رده & نام يذيرفته شده & EC. number & رديف \\
\hline$\wedge$. & مشترى & ترانسفرازها & N-يوتريسين متيل ترانسفراز & [EC:2.1.1.53] & 1 \\
\hline$\wedge$ & 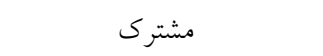 & اكسيدازها & آمين اكسيداز & [EC:1.4.3.21] & r \\
\hline$\lambda r$ & آترويين & هيدرولازها & ترويين استراز-آتروييناز & [EC: 3.1.1.10] & $r$ \\
\hline$\lambda r$ & اسكويلامين & هيدرولازها & هيو سيامين -(6s)-دى اكسيزناز & [EC:1.14.11.11] & $r$ \\
\hline$\wedge \uparrow$ & هيوسيامين & اكسيدازها & آمين اكسيداز & [EC:1.4.3.21] & 0 \\
\hline$\lambda \uparrow$ & 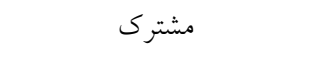 & اكسيدازها & I ترويينون ردو كتاز & [EC 1.1.1.206] & 9 \\
\hline$\lambda \kappa^{4}$ & 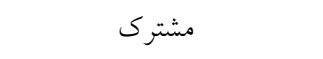 & اكسيدازها & II ترويينون ردوكتاز & [EC 1.1.1.236] & v \\
\hline
\end{tabular}

مهندسى زنتيك مراحل براى افزايش فعاليت آنزيم، فرابيان زن

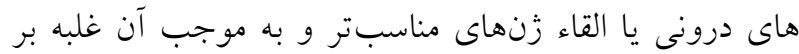
مراحل محدودكننده سرعت در مسير تا متوقف ساختن مسيرهاى رقابت كننده و كاهش كاتابوليسم هيوسيامين مى مئر

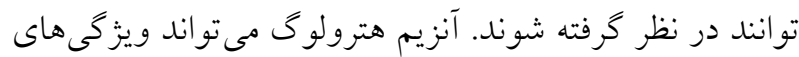

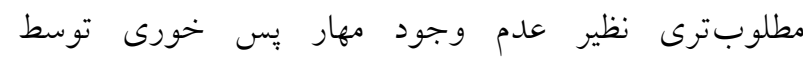
محصولات بِيين دستى يا تمايل بيشتر براى سوبسترا داشته
دستورزى زنهاى مسيربيوسنتز آلكالوئيدهاى ترويانى آتروبين، هيوسيامين و اسكويولامين

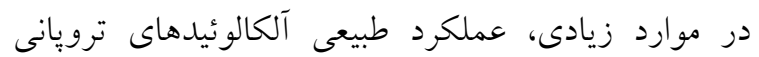
براى تجارىسازى بسيار كم است. لذا نياز براى افزايش

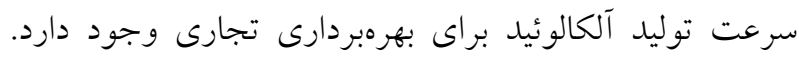

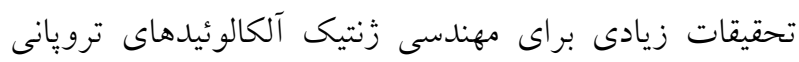

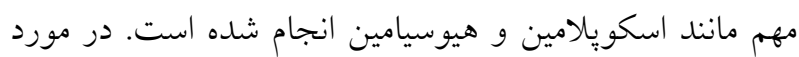


به الكوى تجمع يكسان متابوليت ثانويه نمىشود [M [M]. علاوه

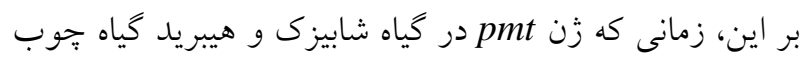

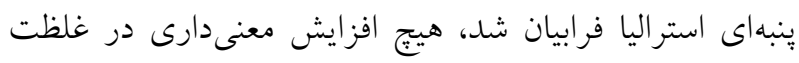

هاى آلكالوئيد ترويان و بيريدين مشاهده نشد [19].

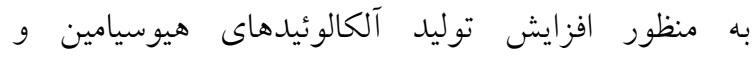
اسكويولامين، سيستم باينارى براى وارد نمودن

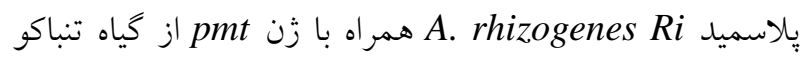

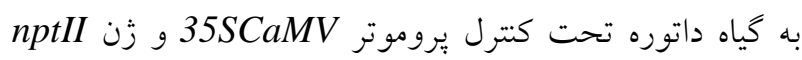

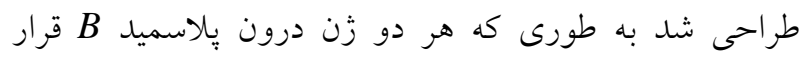
كرفتند. تنظيم بيان زن pmt نشان داده شد كه براى تولئ دوليد

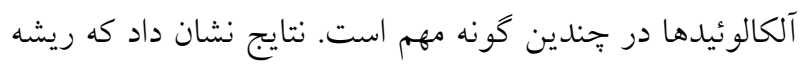

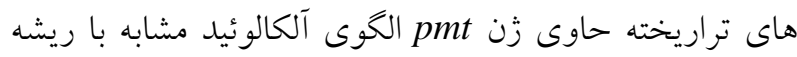

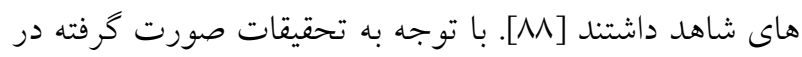
زمينه دستورزى زن pmt در مسير بيوسنتز آلكالوئيدهاى

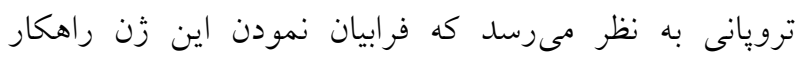

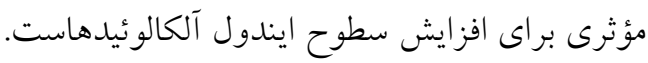

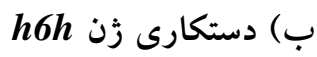

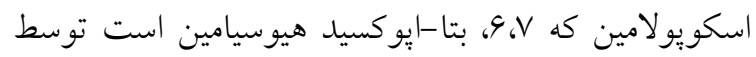
9 بتا-هيدروكسى هيوسيامين توليد مى شود. هيوسيامين 9 بتا-

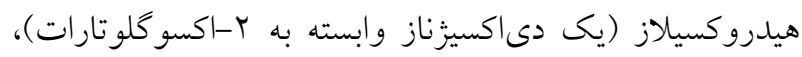

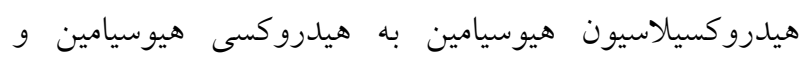

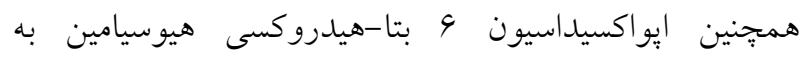

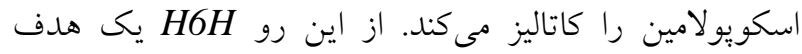

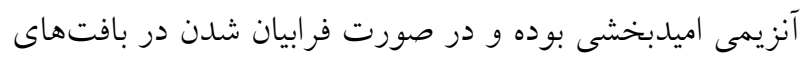

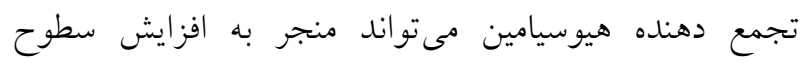

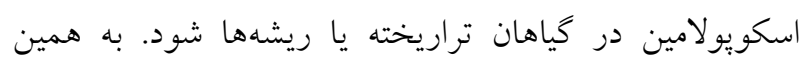

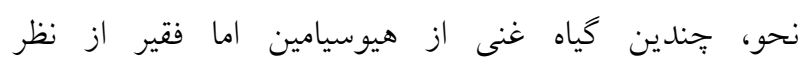

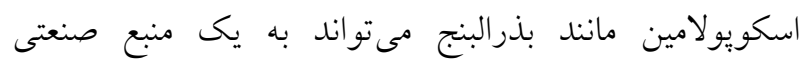

$$
\text { اسكويو لامين تبديل شوند. }
$$

محققان تحقيقات مربوط به مهندسى زنتيك ترويان

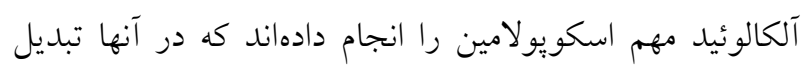

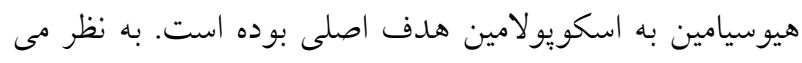

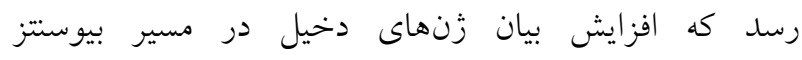

باشند. اينخونه آنزيم مىتواند از منبع ديكر باشد اما هم:جنين

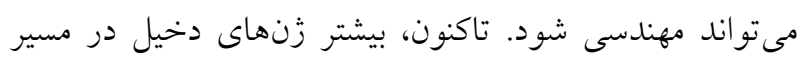

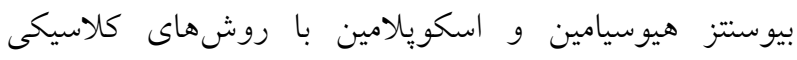

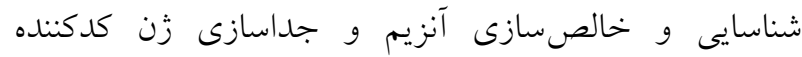
همسانهسازى شدهاند. cDNA هاى كد كننده PMT

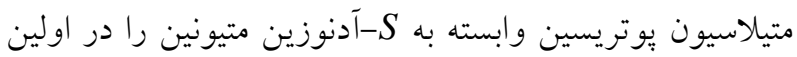

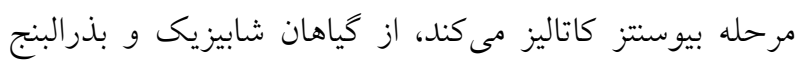
جداسازى شدهاند [عی، هــ].

pmt الف) دستكارى زن بيان شده است كه فرابيان pmt در كياهان تراريخته Nicotiana sylvestris

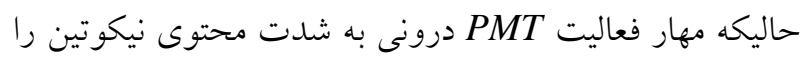

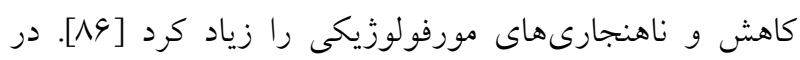

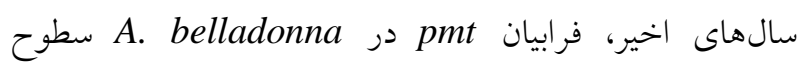

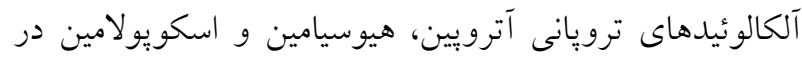

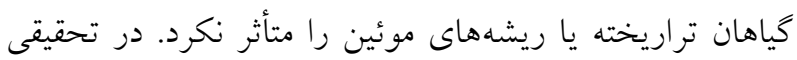

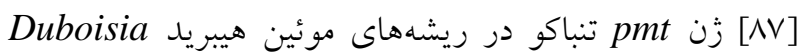

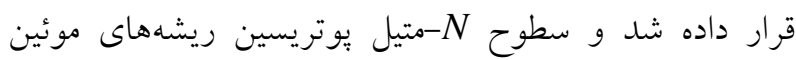

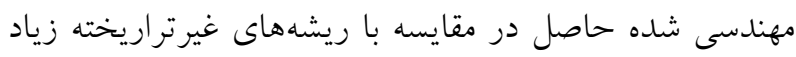

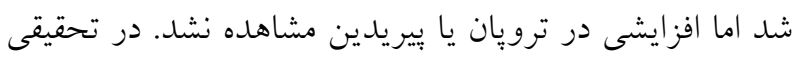

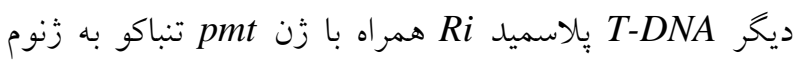
Hyoscyamus muticus و Datura metel

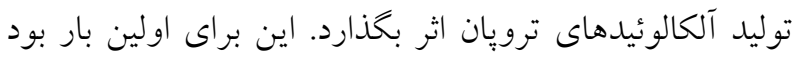

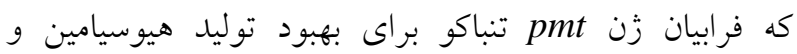

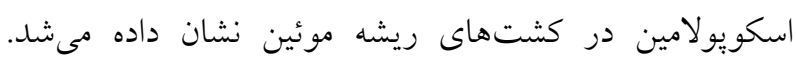

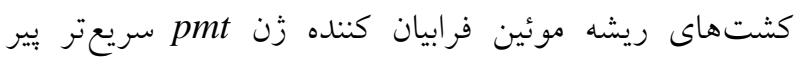

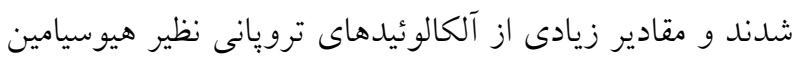

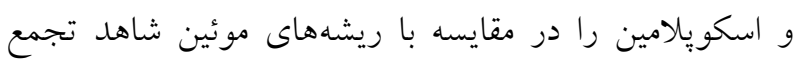
دادند. توليد هيوسيامين و اسكويلامين در كشتهاى ريشه

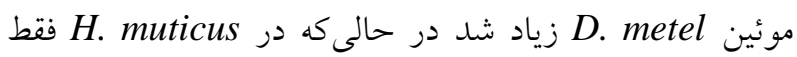

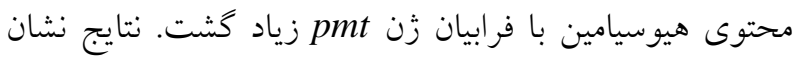

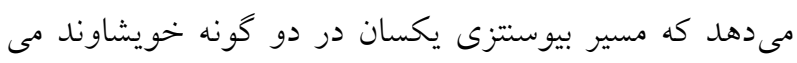

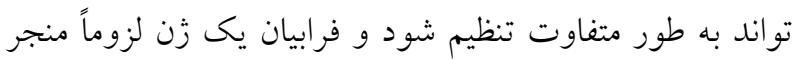


و h6h به طور معنى دارى سطوح بالاى هيوسيامين و

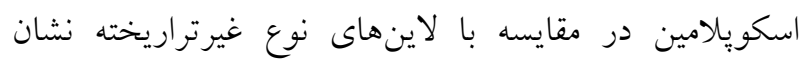

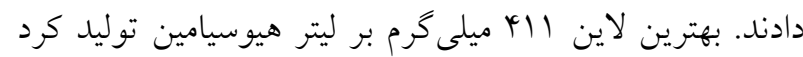

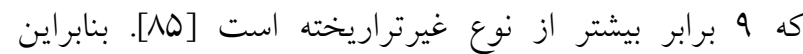

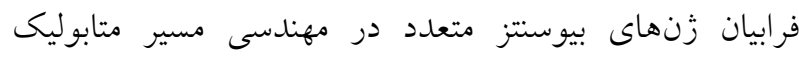

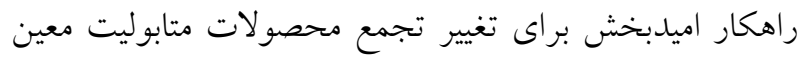

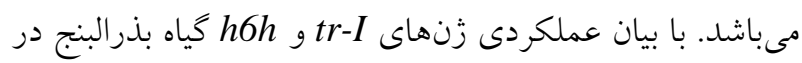

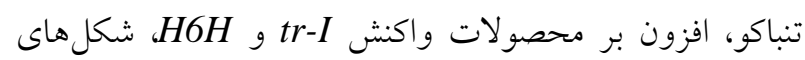

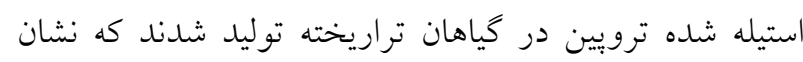

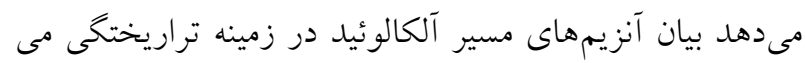

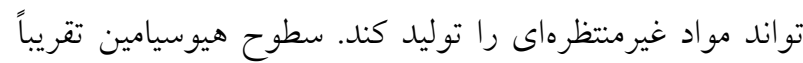

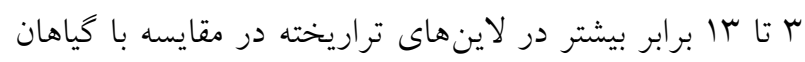

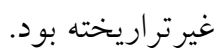

نحوه تهيه نمونه و آناليز آلكالوئيدهاى ترويانى آتروبين، اسكويولامين و هيوسيامين - روشهاى مختلف تهيه نمونه

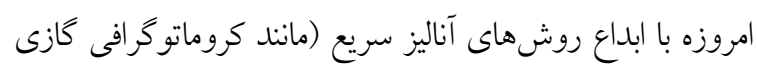

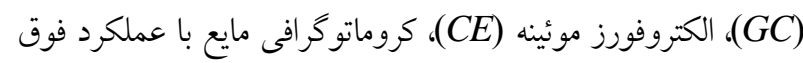

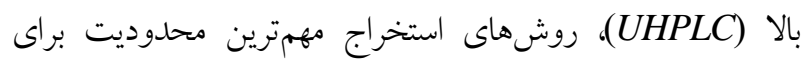

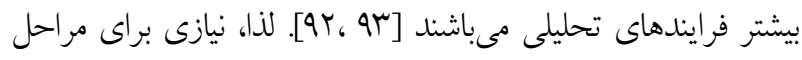

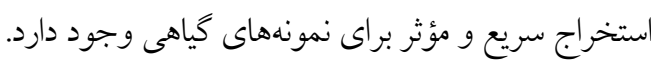

\section{Microwave-assisted (الف) استخراج با استفاده ازميكروويو} (extraction

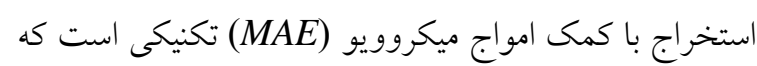

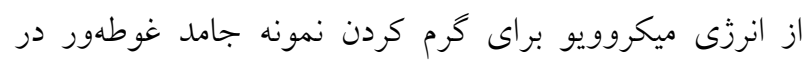

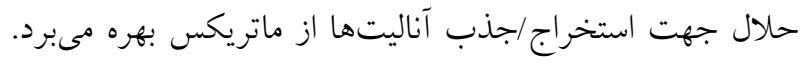

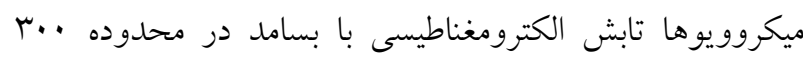

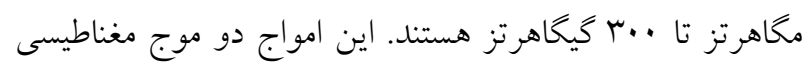

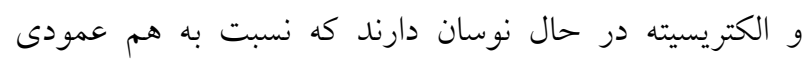

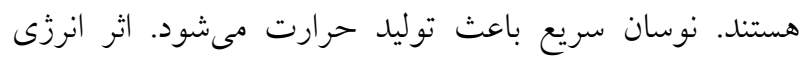

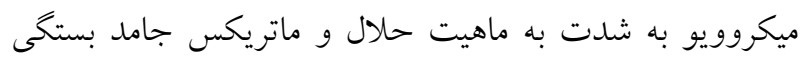

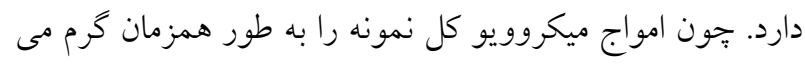

اسكويولامين باعث افزايش اين محصول مىشود. همبستخى في

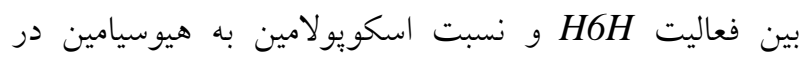

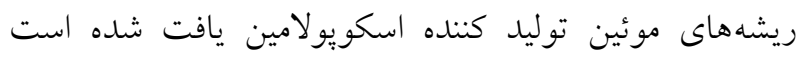

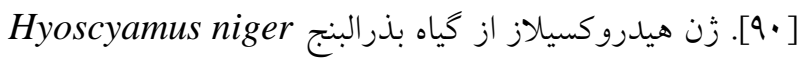

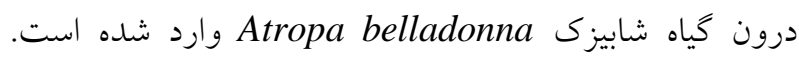

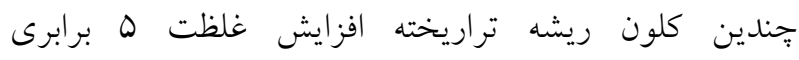
اسكويو لامين در مقايسه با ريشههاى موئين غيرتراريخته داشت فئن

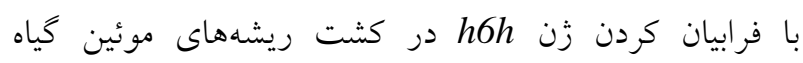
Hyoscyamus muticus

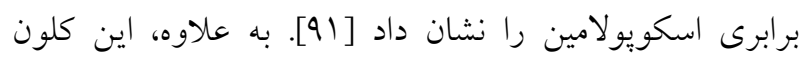

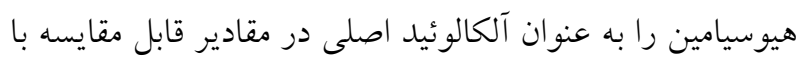

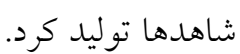

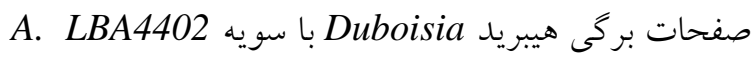
rhizogenes

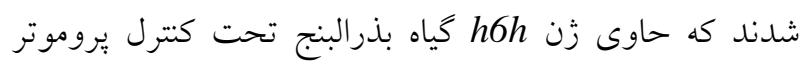
35SCaMV

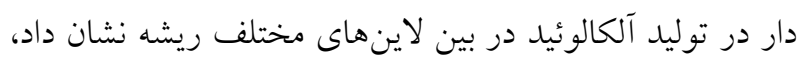

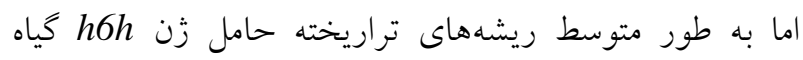

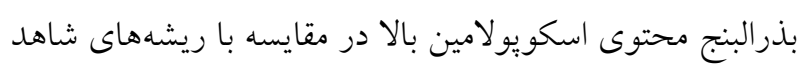

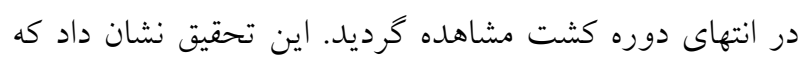

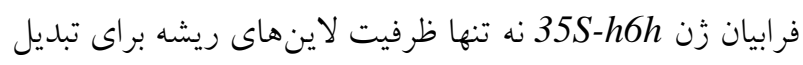

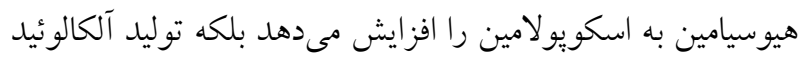

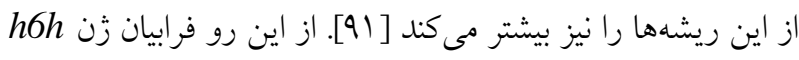

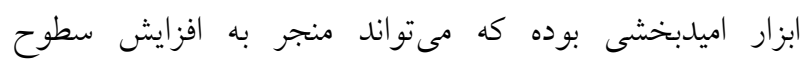
اسكويو لامين در گياهان تراريخته يا ريشهها كردد.

دستكارىزنهاىمختلف دخيل درمسير بيوسنتز آلكالوئيدهاى ترويانى

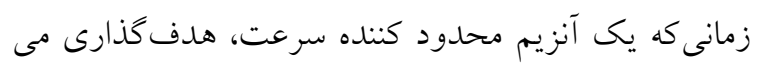

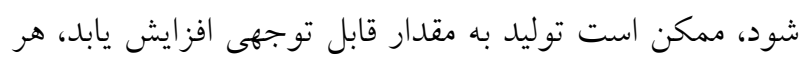

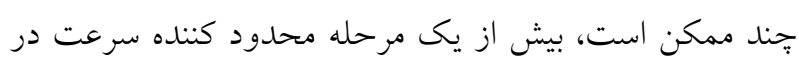

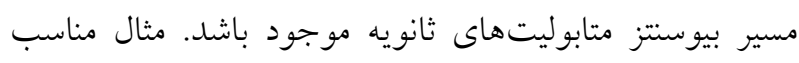

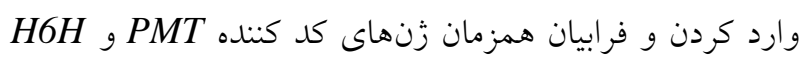

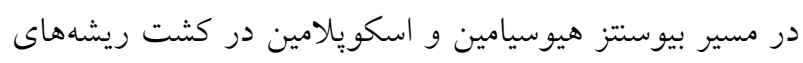

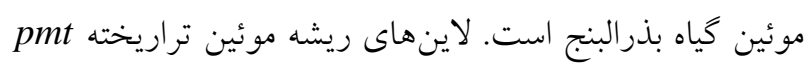


كه CO2 فوق بحرانى همراه با متانول به عنوان تغييردهنده قطبى

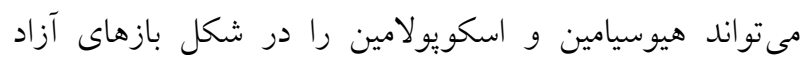

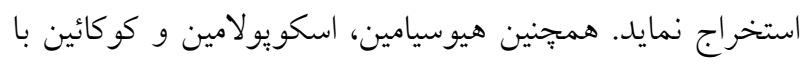

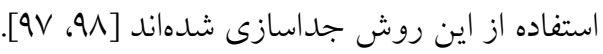

\section{روشهاى آناليز آلكالوئيدهاى ترويانى}

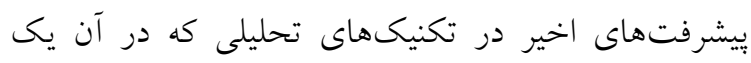

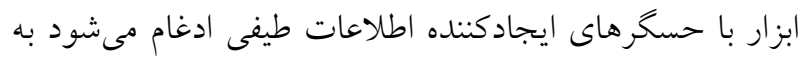

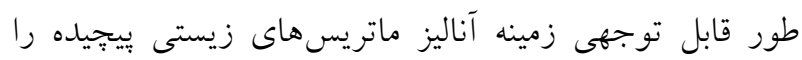

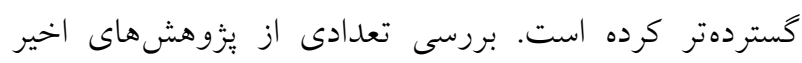

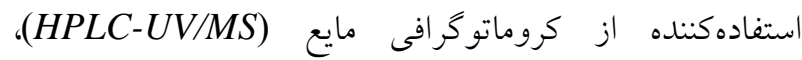

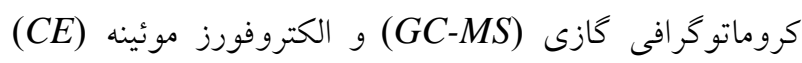

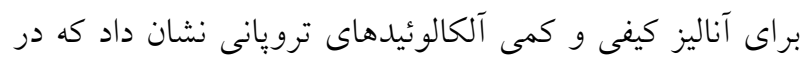

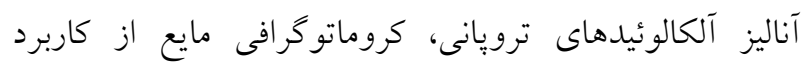

$$
\text { بيشترى برخوردار است (شكل شماره 9). }
$$

$$
\text { الف) كروماتو گرافى مايع }
$$

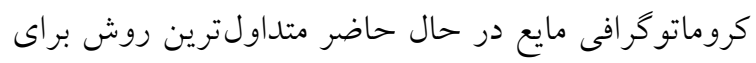

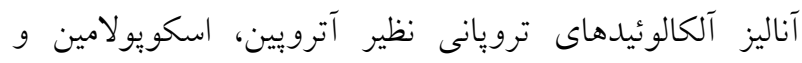

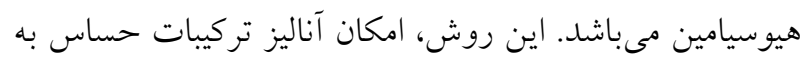

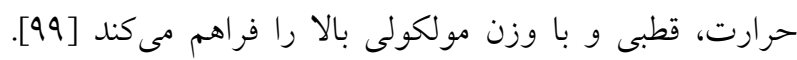

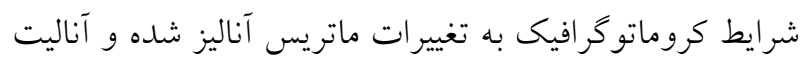

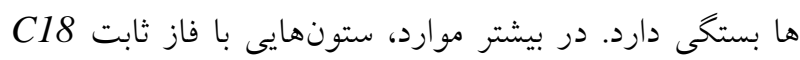

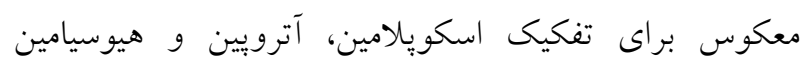

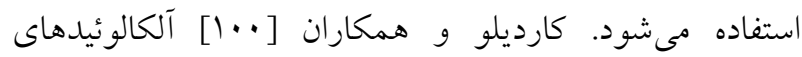

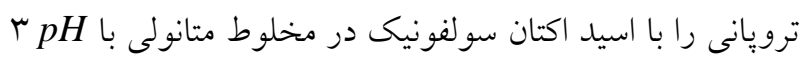

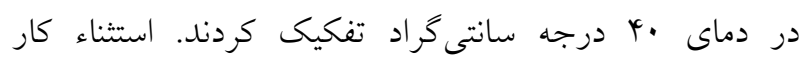

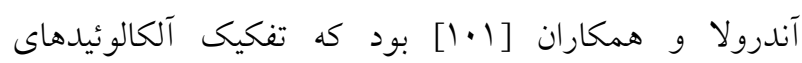

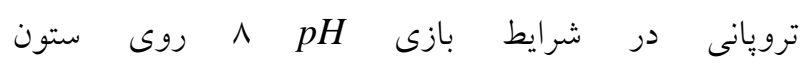
C18Phenomenex Hypersil

$$
\text { استونيتريل به دست آوردند. }
$$

كند، از اين رو منجر به استخراج سريع و مؤثر مىشود [94]. كزارش شده است كه عصارههاى توليد شده توسط امواج

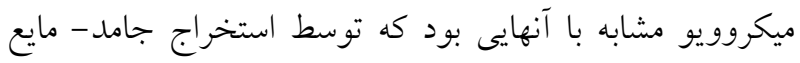

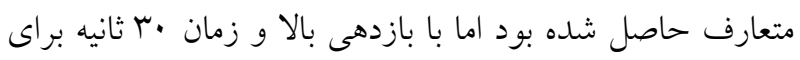

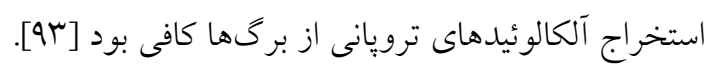

Pressurized liquid ( استخراج با مايع تحت فشار (extraction استخراج با مايع تحت فشار (PLE) يك تكنيك استخراج دوستدار محيط زيست است جون به مقدار كمى از حلال نياز

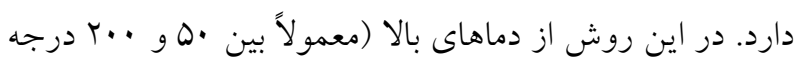

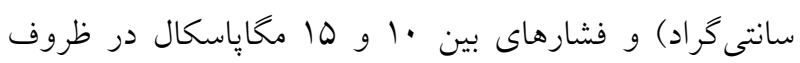

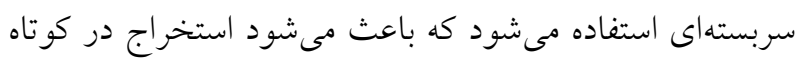

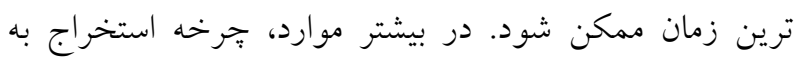

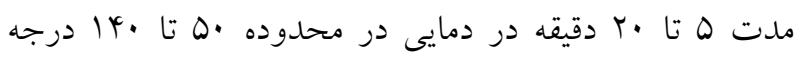

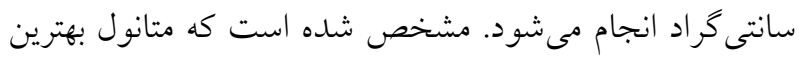

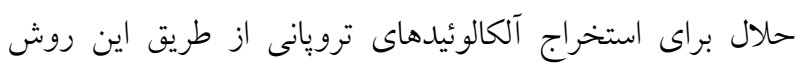

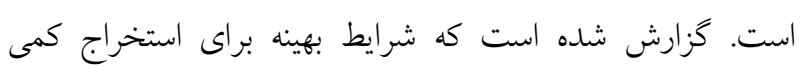

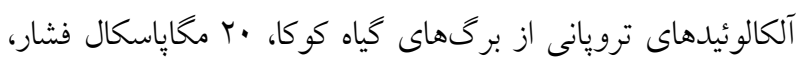

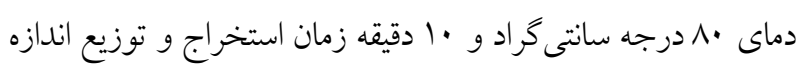

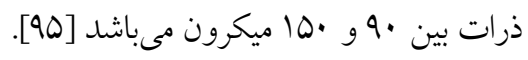

\section{ج) استخراج سيال فوق بحرانى ( Supercritical fluid} (extraction

استخراج سيال فوق بحرانى (SFE) يك جايكزين بسيار عالى براى روشهاى متعارف است. سيالات فوق بحرانى داراى

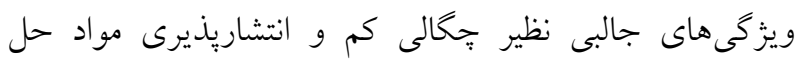

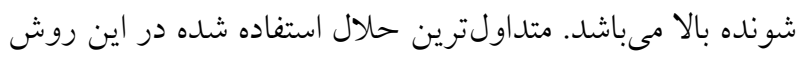

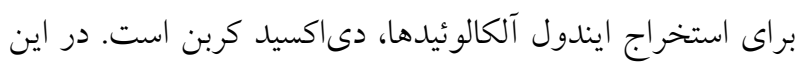

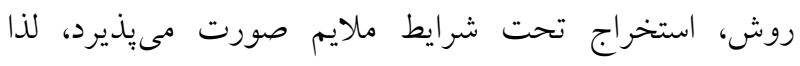

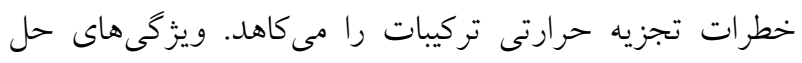

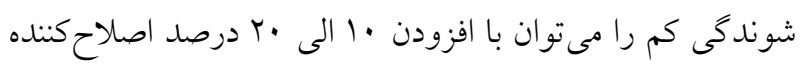

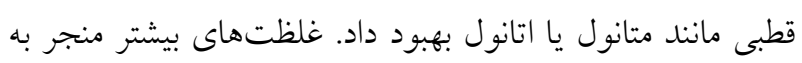
شرايط زير بحرانى مىشود. جويى و همكاران [99] نشان دادند 
نوهسى و همكاران

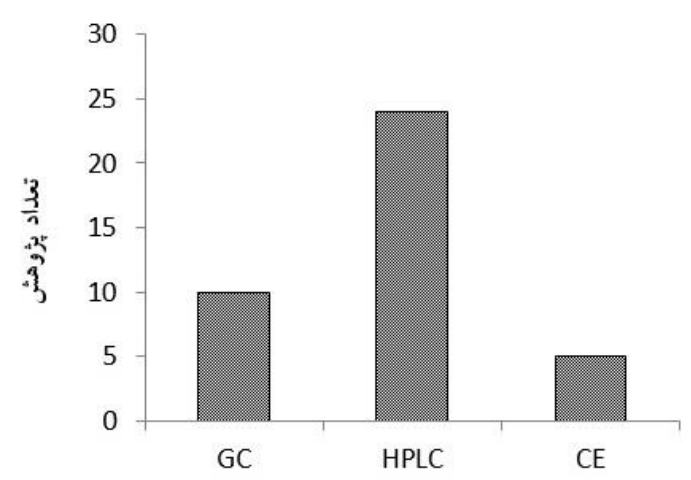

روشهاى آناليز آلكالوئيدهاى ترويانى

شكل شماره 9- روشهاى آناليز مورد استفاده در جه ئزوهش مورد مطالعه

شد، آلكالوئيدهاى ترويانى به دليل جذب ضعيف نور UV باز هم با GC مورد آناليز قرار مى كرفتند. تشخيص آلكالوئيدهاى

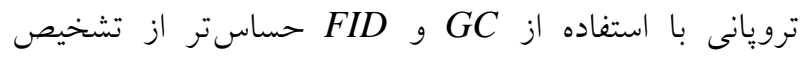

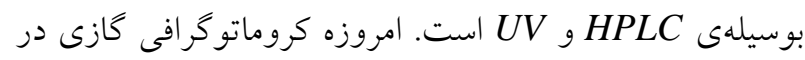

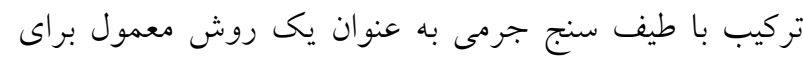

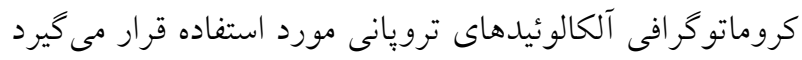

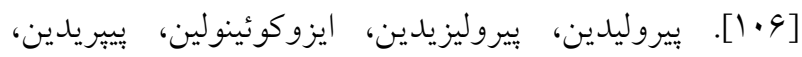

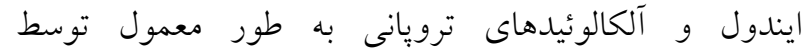

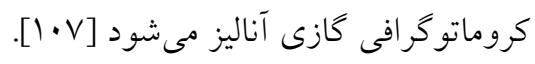

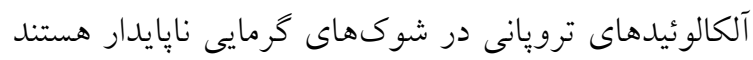

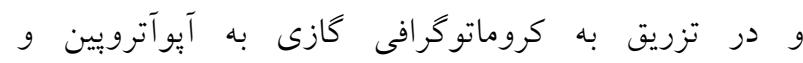

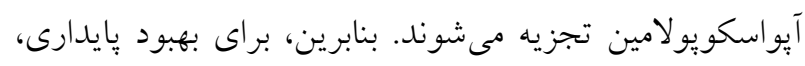

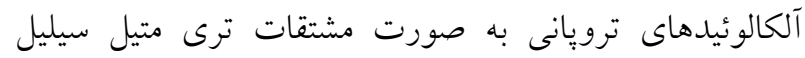

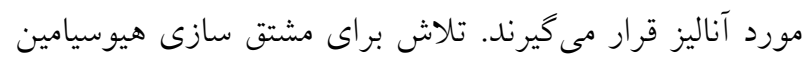

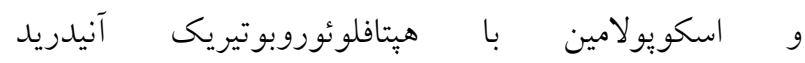
ناكام بود. برخى از (heptafluorobutyric anhydride) واكنشهاى سيلايت كردن (BSTFA)، BSTA-TMCS BSTFA- مورد بررسى قرار كرفتند. مشتق (MBTFA و B. BSA (99:1) TMCS

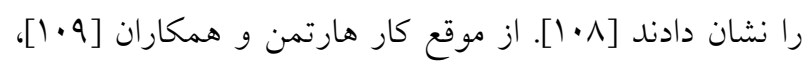

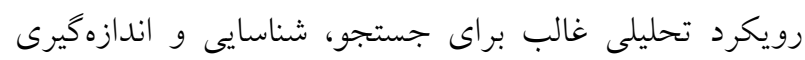

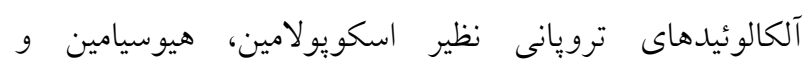
آترويين، GC موئينه همراه با جرم سنج تودهائ با اثر الكير الكترون (GC/EI/MS) تفكيك بالاى ستونهاى موئينه و اطلاعات ساختارى توسط اصلى
كروماتوكرافى مايع غالباً با UV، آرايههاى ديود، ELSD، MS

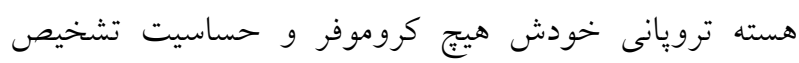

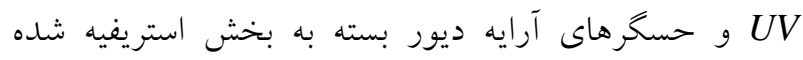

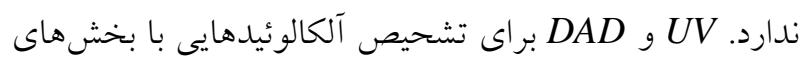

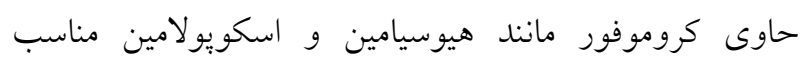

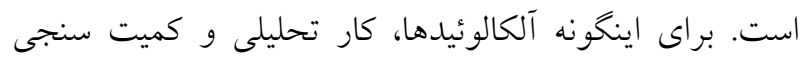

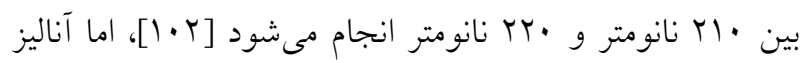

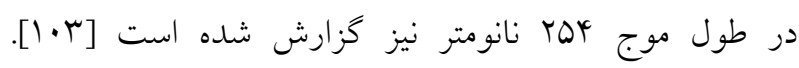

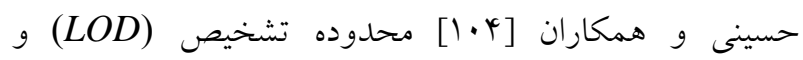

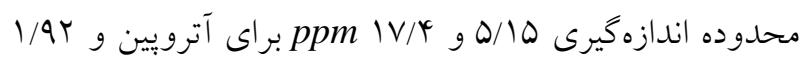

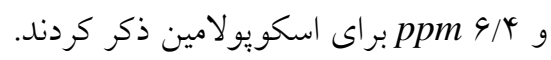

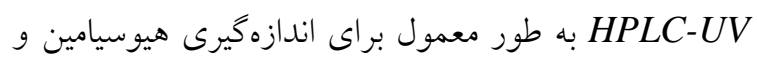
اسكويولامين توليد شده در كشتهاى بافت در شرايط اين ويترو

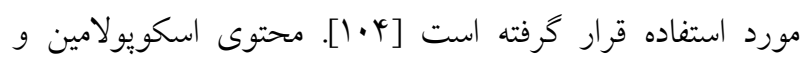
هيوسيامين جهار كونه Hyoscyamus رشد يافته در مناطق مختلف جغرافيايى توسط بهمنزادگان و همكاران اندازهكيرى

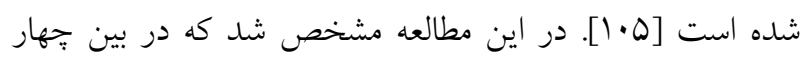

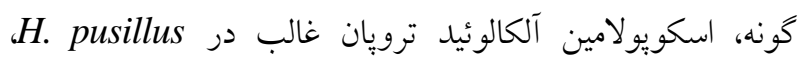
H. reticulatus بود، در حالى كه H. kurdicus و Higer حاوى مقادير بالايى از هيوسيامين بود.

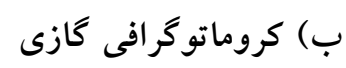

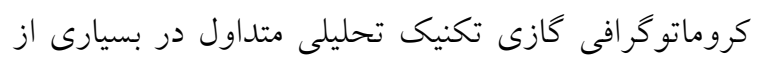

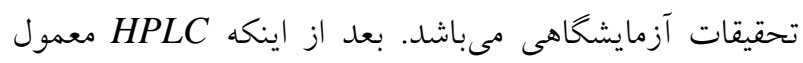


ميلى مولار بر ليتر فسفات و \٪ متانول در

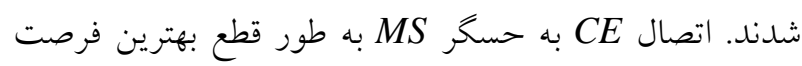

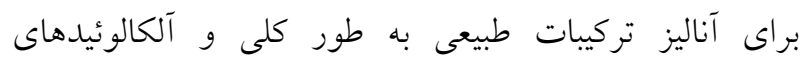

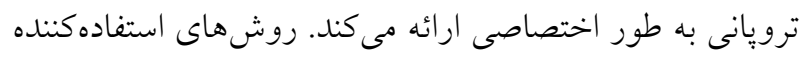

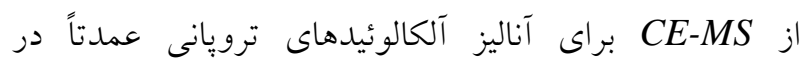
آزمايشگاههاى بالينى و جنايى توسعه يافتهاند.

\section{نتيجه گيرى}

آلكالوئيدهاى ترويانى آترويين، اسكويولامين و هيوسيامين از

اهميت شايانى در صنايع داروسازى برخوردار هستند. كياهان

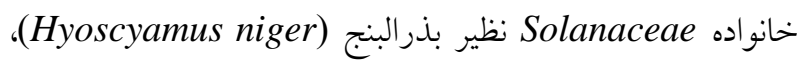
شابيزى (Atropa belladonna) و دوبوزيا (Duboisia)

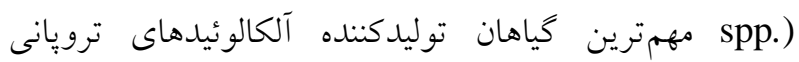

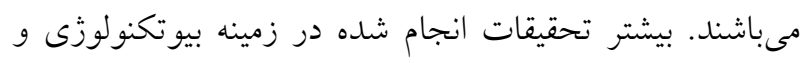

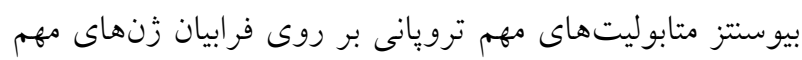

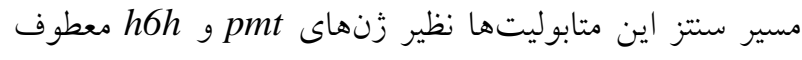

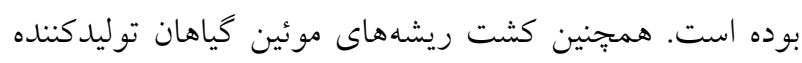

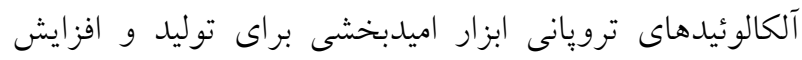

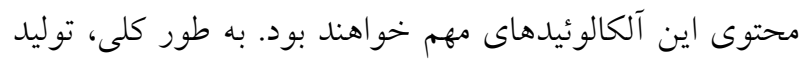

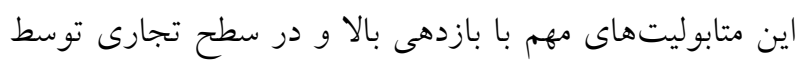
روشهاى نوين تحت بررسى و مطالعه است. به نظر مىرسد

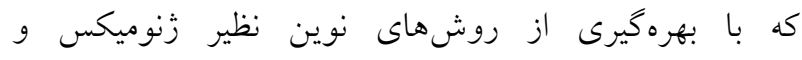

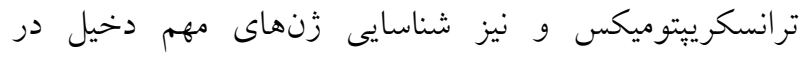

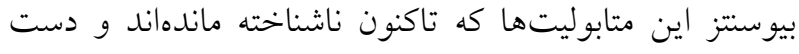

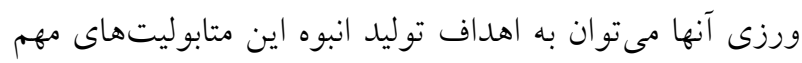
و مواد اوليه كياهى با كيفيت در سطح تجارى به براى صنايع

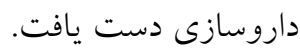

1. Kukula-Koch WA and Widelski. J. Alkaloids. In: Simone Badal and Rupika Delgoda, pharmacognosy: Fundamentals, Applications and Strategies. Academic Press. 2017, pp: 163-98.
حسكر جرمى است. محدوديتها و مزيتهاى GC-MS براى

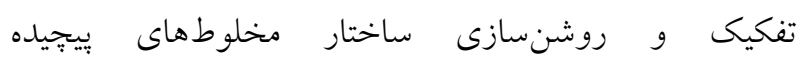
آلكالوئيدهاى ترويانى در كار البزويى و همكاران [TV] نشان

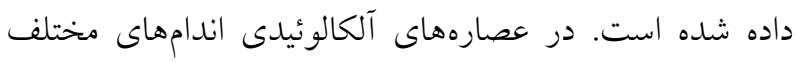

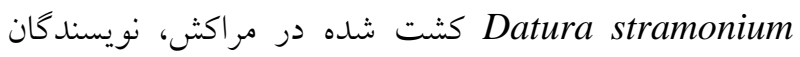

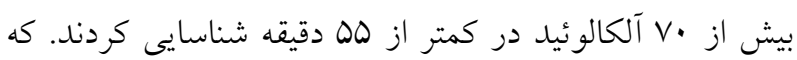

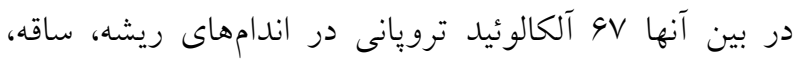
برى، بذر و گل ها شناسايى شدند.

\section{ج) الكتروفورز موئينه}

الكتروفورز موئينه به دليل بازدهى، دقت و و وضوح بـائه بالا در

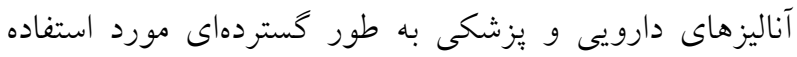

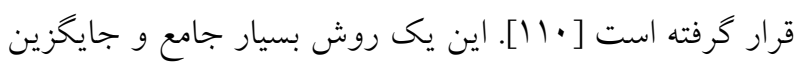

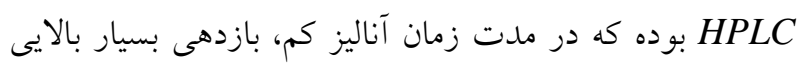

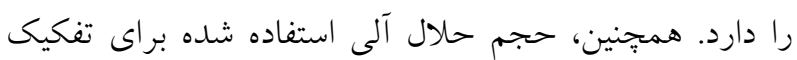

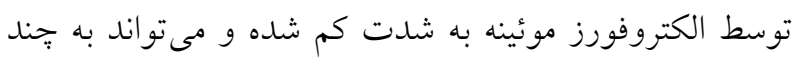
ميلى ليتر در هر روز برسد [111].

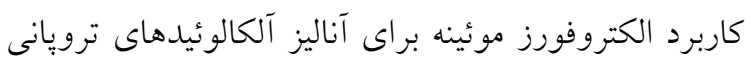
در ماتريسهاى مختلف مرور شده است. يكى از مزيتهاى

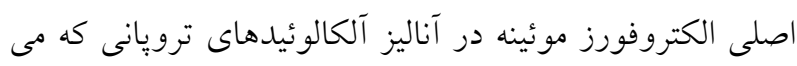

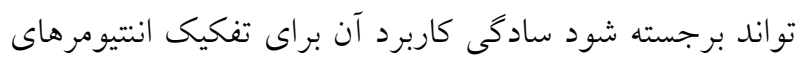

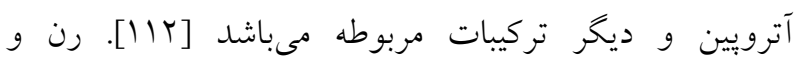

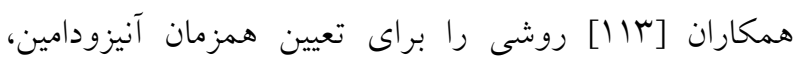

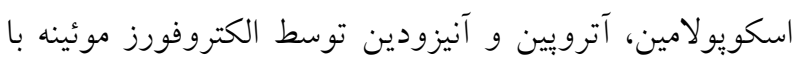

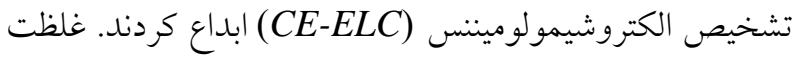

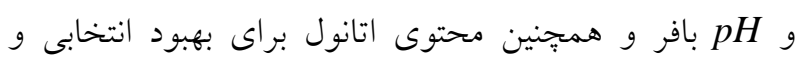

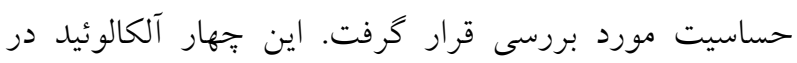

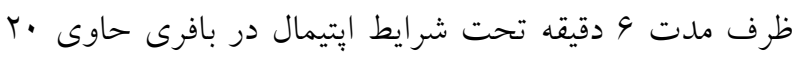

\section{منابع}

2. Dewick PM. Medicinal natural products. A biosynthetic approach. 3rd ed. The Atrium, United Kingdom: John Wiley \& Sons Ltd. 2009, pp: 311481 . 
3. Aniszewski T. Alkaloidssecrets of life. Alkaloid chemistry, biological significance, applications and ecological role, vol. 56, 710. The Netherlands: Elsevier B.V. 2007, pp: 182-9.

4. Lounasmaa $M$ and Tamminen $T$. The tropane alkaloids. In: Cordell GA. (eds.). The Alkaloids. Academic, New York. 1993, 44, pp: 1-114.

5. O'Leary ME, Hancox JC. Role of voltagegated sodium, potassium and calcium channels in the development of cocaine-associated cardiac arrhythmias. Br. J. Clin Pharmacology. 2010; 69 (5): 427-42.

6. Keil $M$ Fine chemicals from plants. In: Oksman-Caldentey KM, Barz WH (eds) Plant Biotechnology and Transgenic Plants, Marcel Dekker, Inc., NY. 2002, pp: 347-72.

7. Chevallier, MA. The encyclopedia of medicinal plants; Dorling kindersly. 1996, pp: 336.

8. Brown JH., Taylor P.Muscarinic receptor agonists and antagonists. In: Hardman, J.G., et al. (Eds.), The Pharmacological Basis of Therapeutics. McGraw-Hill, New York. 1996, pp: 141-60.

9. Kitagawa I, Ishizu T, Ohashi K, Shibuya H. Chirality of natural products: hyoscyamine and scopolamine. Yakugaku Zasshi. 2000; 120: 101723.

10. Budavari S, Windholz M. Hyoscamine. In: The merck index: An encyclopedia of chemicals, drugs, and biologicals, 12th edn. Merck. 1996, pp: 148-9.

11. O'Neil MJ. The merck index - An encyclopedia of chemicals, drugs, and biologicals. whitehouse station, NJ: Merck and Co., Inc. 2006, p. 1450.

12. Lide DR. Handbook of Chemistry and Physics. CRC Press, Taylor \& Francis, Boca Raton, FL. 2007, p. 3-458.

13. Budavari $S$, Windholz $M$. Atropine. In the merck index: An encyclopedia of chemicals, Drugs, and Biologicals, 12th edn. Merck. 1996, pp: 148-9.

14. The Merck Index. 9th ed. Rahway, New Jersey: Merck \& Co., Inc. 1976, p: 647.
15. Lide, DR. Handbook of Chemistry and Physics. 81st Edition. CRC Press LLC, Boca Raton: FL. 2000, p: 3-27.

16. Weast RC. Handbook of Chemistry and Physics. 60th ed. Boca Raton, Florida: CRC Press Inc. 1979, p: C-346.

17. Sunshine I. Handbook of Analytical Toxicology. Cleveland: The Chemical Rubber Co., 1969, p: C-13.

18. Trissel LA. Handbook on Injectable Drugs. 9th ed. Bethesda, MD. American Society of HealthSystem Pharmacists' Product Development. 1996, p: 109.

19. Lewis RJ. Sax's Dangerous Properties of Industrial Materials. 9th ed. Volumes 1-3. New York, NY: Van Nostrand Reinhold. 1996, p: 289.

20. Parfitt K. Martindale: The complete drug reference, $32^{\text {nd }}$ ed. The Pharmaceutical Press London 1999, p: 455-7.

21. Dei S, Bartolini A, Bellucci C, Ghelardini C, Gualtieri F, Manetti D, Romanelli MN. Scapecchi S, Teorodi E. Differential analgesic activity of the enantiomers of atropine derivatives does not correlate with their muscarinic subtype selectivity. Eur. J. Med. Chem. 1997; 32: 595-605.

22. Osol, A. (ed.). Remington's Pharmaceutical Sciences. 16th ed. Easton, Pennsylvania: Mack Publishing Co. 1980, p: 856.

23. Griffin WJ, Lin GD. Chemotaxonomy and geographical distribution of tropane alkaloids. Phytochem. 2000; 53: 623-37.

24. Ghorbanpour M, Salehi Arjmand H, Hatami M, Hosseini N. Evaluation of morphological and tropane alkaloids variability in some populations of Hyosscyamus niger L. JMP. 2018; 17 (2): 105-24.

25. El Bazaoui A, Bellimam MA, Soulaymani A. Nine new tropane alkaloids from Datura stramonium L. identified by GC/MS. Fitoterapia. 2011; 193-7. doi:10.1016/j.fitote.2010.09.010.

26. Ionkova I, Witte L, Alfermann HA. Spectrum of tropane alkaloids in transformed roots of Datura

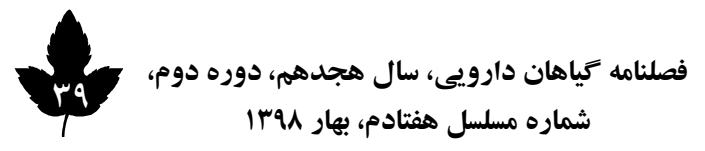


quercifolia and Hyoscyamus $\times$ gyorffyi cultivated in vitro. Planta Med. 1994; 60: 382-4.

27. Vitale AA, Archer A, Pomilio AB.Alkaloids of Datura ferox from Argentina. J. Ethnopharmacol. 1995; 49: 81-9

28. Evans WC, Somanabandhu, A. Alkaloids of Datura discolor. Phytochem. 1974; 13:304-305.

29. Evans W. C. and Wellendorf M. The alkaloids of the roots of datura. J. Chem. Soc., 1959; 0: 1406-9.

30. Strahil Berkov, Rawia Zayed, Tsvetelina Doncheva. Alkaloid patterns in some varieties of Datura kymatocarpa. Fitoterapia 2006; 77: 179-82.

31. Evans WC and Major VA. The alkaloids of the genus Datura. Part V. Alkaloids of Datura sanguinea $\mathrm{R}$. and $\mathrm{P}$. and related esters of tropane3a. J. Chem. Soc (C). 1968; 22: 2775-8.

32. Kariñho-Betancourt A, Agrawal AA, Halitschke R, Núñez-Farfán J. Phylogenetic correlations among chemical and physical plant defenses change with ontogeny. New Phytol. 2014; 206: 796-806.

33. Rätsch C. The Encyclopedia of Psychoactive Plants: Ethnopharmacology and its applications. Park Street Press, Rochester, USA. 1998.

34. Bye R, Mata R, Pimentel J. Botany, ethnobotany and chemistry of Datura lanosa (Solanaceae) in Mexico. Anales del Instituto de Biologia de la Universidad Nacional Autónoma de México, Serie Botánica 1991; 61: 21-42.

35. Lindequist UDatura. In: Hagers handbuch der pharmazeuti-schen Praxis, 5th edn. Springer, Berlin. 1992, pp: 1138-54.

36. Parr J, Payne J, Eagles J, Champan BT, Robins RJ, Rhodes MJC. Variation in tropane alkaloids accumulation within the Solanaceae and strategies for its exploitation. Phytochem. 1990; 29: 2545-50.

37. Samanani N, and Facchini P J. Compartmentalization of plant secondary metabolism. Recent Advances in Phytochemistry. 2006; 40: 53-83.
38. Zhang L. Ding, R, Chai Y, Bonfill M, Moyano E, Oksman-Kaldenty K.M, Xu T, Pi Y, Wang Z, Zhang H, Kai G, Liao Z, Sun X, Tang, K. Engineering tropane biosynthetic pathway in Hyoscyamus niger hairy root cultures. Proc. Natl. Acad. Sci. 2004; 101: 6786-91.

39. Kutchan TM, Frick S, Weid M. Engineering plant alkaloid biosynthetic pathways: progress and prospects. Adv. Plant Biochem. Mol. Biol. 2008; 1 : 283-310.

40. Ziegler J, Facchini, PJ. Alkaloid biosynthesis: Metabolism and trafficking. Annu. Rev. Plant Biol. 2008; 59: 735-69.

41. Samuelsson G. Drugs of natural origin: A Textbook of pharmacognosy. Swedish Pharmaceutical Press, Stockholm. 2001.

42. Ghorbanpour M, Majnoun Hoseini N, Rezazadeh Sh, Omidi M, Khavazi K, Hatami M. Variations of root and shoot tropane alkaloids production of Hyoscyamus niger under two rhizobacteria strains inoculation and water deficit stress. JMP. 2011; 10 (40): 160-70.

43. Ghorbanpour M, Khavazi K, Ghafarzadegan R, Hatami M. Two main tropane alkaloids variations of black henbane (Hyoscyamus niger) under PGPRs inoculation and water deficit stress induction at flowering stage. JMP. 2013; 12 (45): 29-42.

44. Aigner TG, Mishkin M. The effects of physostigmine and scopolamine on recognition memory in monkeys. Behav Neural Biol. 1986; 45: 81-7.

45. Spinks A. and Wasiak J. Scopolamine (hyoscine) for preventing and treating motion sickness. Cochrane database Syst. Rev. DOI: 10.1002/14651858 (2011).

46. Shiraishi K and Takayanagi I. Subtype of muscarinic receptors mediating relaxation and contraction in the rat iris dilator smooth muscle. Gen. Pharmacol. 1993; 24 (1): 139 - 42. 
47. Jones DNC and Higgins GA. Effect of scopolamine on visual attention in rats. Psychopharmacol. 1995; 120: 142-9.

48. Tobin G, Giglio D. and Gotrick, B. Studies of muscarinic receptor subtypes in salivary gland function in anaesthetized rats. Autonomic Neuroscience: Basic and Clinical. 2002; 100: 1-9.

49. Eglen RM, Hedge SS. andWatson N. Muscarinic receptor subtypes and smooth muscle function. Pharmacol. Rev. 1996; 48 (4): 531-65.

50. Chintoh A, Fulton J, Koziel N, Aziz M, Sud M. and Yeomans JS. Role of cholinergic receptors in locomotion induced by scopolamine and oxotremorine-M. Pharmacol. Biochem. Behav. 2003; 76: 53-61.

51. Dai Y, Ambudkar IS, Horn VJ, Yeh C, Kousvelari EE, Wall SJ, Li M, Yasuda RP, Wolfe $\mathrm{BB}$ and Baum BJ. Evidence that M3 muscarinic receptors in rat parotid gland couple to two second messenger systems. Am. J. Physiol. 1991; 261: 1063-73.

52. McGaughy J, Everitt BJ, Robbins $T W$ and Sarter, M., The role of cortical cholinergic afferent projections in cognition: impact of new selective immunotoxins. Behav. Brain. Res. 2000; 115: 25163.

53. DeFrates LJ, Hoehns JD, Sakornbut EL, Glascock DG, Tew AR. Antimuscarinic intoxication resulting from ingestion of moonflower seeds. Ann. Pharmacother. 2004; 39: 173-6.

54. Bruce N. Alkaloids. In: Rehm HJ. Reed G. and Bruce NC. (Eds.), Biotechnology Set. Wiley, Cambridge, UK. 2008, pp: 332-50.

55. Guggisberg G. and Hesse, M. The alkaloids: chemistry and pharmacology. Academic, New York. 1983, 22: 85-188.

56. Ghelardini C.Galeotti N. Gualtieri F. Bellucci C. and Bartolini A. Memory facilitation with atropine: A paradoxical effect. Phytotherapy Res. 1998; 12: 7-9.
57. Lopez-Enriquez E, Raphael Morales A, and Robert F.Effect of atropine sulfate in pulmonary hypertrophic osteoarthropathy. Arthritis Rheum. 1980; $23: 7$.

58. Clement JG and Lee MJ. Pharmacokinetics of the acetylcholinesterase oxime reactivator, HI-6, in rhesus monkeys (Macaca mulatta): Effect of atropine, diazepam, and methoxyflurane anesthesia. Biopharm. Drug Dispos. 1990; 11: 227-32.

59. Blozovski D and Bachevalier J. Effect of atropine on behavioral arousal in the developing rat. Dev. Psychol. 1975; 8 (2): 97-102.

60. Li S, Topchiy I, and Kocsis B. The effect of atropine administered in the medial septum or hippocampus on high- and low-frequency theta rhythms in the hippocampus of urethane anesthetized rats. Synapse 2007; 61: 412-9.

61. Wilson LM and Ricci DC. Scopolamine's effect on passive avoidance behavior in immature rats. Dev. Psychobiol. 1976; 9 (3): 245-4.

62. David M. Warburton. Commentary on: Effects of scopolamine and nicotine on human rapid information processing performance. Psychopharmacology 1984; 82: 147-50.

63. Poorheidari G, Pratt JA and Dehghan N. Effects of low-dose scopolamine on locomotor activity: No dissociation between cognitive and non-effects. Neurosci. Res. Comuni. 31 (3): 15206769.

64. Firth AY and Walker K. Visual side-effects from transdermal scopolamine (hyoscine). Dev. Med. Child. Neurol. 2006; 48: 137-8.

65. Vesalainen RK, Tahvanainen KUO, Kaila TJ, Kantola IM, Kuusela TA and Eckberg DL. Effects of low-dose transdermal scopolamine on autonomic cardiovascular control in healthy young subjects. Clin. Physiol. 1997; 17: 135 - 48.

66. Ricng J, Gualtierib $F$ and Tucek S. Constitutive inhibitory action of muscarinic receptors on adenylate cyclase in cardiac membranes: effects of atropine, $\mathrm{S}-(-)$ -

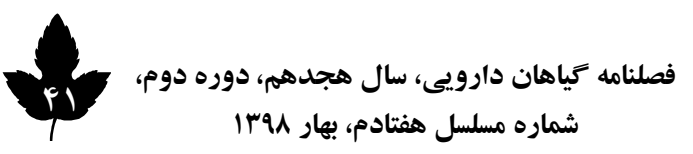


hyoscyamine, and R-(+)-hyoscyamine. 5th International Symposium on Cholinergic Mechanisms. 1998.

67. Rozear M. Bircher RP. Chai CY. Wang SC. Effects of intracerebroventricular L-hyoscyamine, ethybenztropine and procaine on cardiac arrhythmias induced in dogs by pentylenetetrazol, picrotoxin or deslanoside. hat. J. Neurophurmucol. 1968; 7: 1-6.

68. Kim N, Estrada O, Chavez B, Stewart C and D'Auria JC. Tropane and granatane alkaloid biosynthesis: A systematic analysis. Molecules. 2016; 21: 1510; doi: 10.3390/molecules21111510.

69. Hibi N, Fujita T, Hatano M, Hashimoto $T$ and Yamada Y. Putrescine N-methyltransferase in cultured roots of Hyoscyamus albus: n-Butylamine as a potent inhibitor of the transferase both in vitro and in vivo. Plant Physiol. 1992; 100: 826.

70. Stenzel O, Teuber M and Drager B. Putrescine N-methyltransferase in Solanum tuberosum L., a calystegine-forming plant. Planta. 2006; 223: 200.

71. Scholl Y, Hoke D and Drager B. Calystegines in calystegia sepium derived from the tropane alkaloid pathway. Phytochem. 2001; 58: 883.

72. Scholl Y. Schneider B. and Drager B. Biosynthesis of calystegines: $15 \mathrm{~N}$ NMR and kinetics of formation in root cultures of Calystegia sepium. Phytochem. 2003; 62: 325.

73. Sato F. Takeshita N. Fitchen JH. Fujiwara H. and Yamada Y. Metabolic engineering of plant alkaloid biosynthesis. Phytochem. 2001; 98 (1): 367-72.

74. Duran-Patron R. Hagan DO. Hamilton JT. and Wong CW. Biosynthetic studies on the tropane ring system of the tropane alkaloids from Datura stramonium. Phytochem. 2000; 53: 777.

75. Lanoue A, Boitel-Conti M, Portais JC, Laberche JC, Barbotin JN, Christen $\mathrm{P}$ and Sangwan-Norreel B. Kinetic study of littorine rearrangement in Datura innoxia hairy roots by (13) C NMR spectroscopy. J. Nat. Prod. 2002; 65: 1131.
76. Eich E. Ornithine-Derived Alkaloids. In: Eich E. (Eds.) Solanaceae and Convolvulaceae: Secondary Metabolites. Springer-Verlag Berlin Heidelberg. 2008, pp: 33-212.

77. Matsuda J, Okabe S, Hashimoto $\mathrm{T}$ and Yamada Y. Molecular cloning of hyoscyamine 6 beta-hydroxylase, a 2-oxoglutarate-dependent dioxygenase, from cultured roots of Hyoscyamus niger. J. Biol. Chem. 1991; 266: 9460-4.

78. Suzuki K, Yun DJ, Chen XY, Yamada Y and Hashimoto T. An Atropa belladonna hyoscyamine 6beta-hydroxylase gene is differentially expressed in the root pericycle and anthers. Plant Mol. Biol. 1999; 40: 141.

79. Hashimoto T, Hayashi A, Amano Y, Kohno J, Iwanari $\mathrm{H}$, Usuda $\mathrm{S}$ and Yamada $\mathrm{Y}$. Hyoscyamine 6 beta-hydroxylase, an enzyme involved in tropane alkaloid biosynthesis, is localized at the pericycle of the root. J. Biol. Chem. 1991; 266: 4648.

80. Ahmad A, and Leete E. Biosynthesis of tropine moiety of hyoscyamine from $\delta$-Nmethylornithine. Phytochem. 1970; 9: 2345-7.

81. Humphrey AJ and O'Hagan D. Tropane alkaloid biosynthesis. A century old problem unresolved. Nat. Prod. Rep. 2001; 18: 494-502.

82. Dräger B. Tropinone reductases, enzymes at the branch point of tropane alkaloid metabolism. Phytochemistry 2006; 67: 327-37.

83. Portsteffen A, Dräger B.and Nahrstedt A. The reduction of tropinone in Datura stramonium root cultures by two specific reductases. Phytochem. 1994; 37: 391-400.

84. Hashimoto $\mathrm{T}$ and Yamada $\mathrm{Y}$. Alkaloid biogenesis: Molecular aspects. Annu. Rev. Plant Physiol. Plant Mol. Biol. 1994; 45: 257-85.

85. Zhang L, Ding R, Chai Y, Bonfill M, Moyano E, Oksman-Caldentey KM, Xu T, Pi Y, Wang Z, Zhang H, Kai G, Liao Z, Sun $X$ and Tang K. Engineering tropane biosynthetic pathway in Hyoscyamus niger hairy root cultures. PNAS. 2004; 1001: 6786-91. 
86. Sato F, Hashimoto $T$, Hachiya A, Tamura K, Choi K, Morishige T, Fujimoto H and Yamada Y. Metabolic engineering of plant alkaloid biosynthesis. PNAS. 2001; 98: 367-72.

87. Moyano E, Fornalé S, Palazón J, Cusidó R.M, Bagni N and Piñol M.T. Alkaloid production in Duboisia hybrid hairy root cultures overexpressing the pmt gene. Phytochemistry 2002; 59: 697-702.

88. Moyano E, Jouhikainen $K$, Tammela $P$, Palazón J, Cusido RM, Piñol MT, Teeri TH and Oksman-Caldentey KM. Effect of pmt gene overexpression on tropane alkaloid production in transformed root cultures of Datura metel and Hyoscyamus muticus. J. Exp. Bot. 2003; 54: 20311.

89. Rothe G, Drager B. Tropane alkaloidsmetabolic response to carbohydrate signal in root cultures of Atropa belladonna. Plant Sci. 2002; 163: 979-85.

90. Jouhikainen K. Lindgren L, Jokelainen $\mathrm{T}$, Hiltunen R, Teeri TH. and Oksman-Caldentey KM. Enhancement of scopolamine production in Hyoscyamus muticus L. hairy root cultures by genetic engineering. Planta. 1999; 208: 545-51.

91. PalazónJ. Moyano E. Cusido RM. Bonfill M. Oksman-Caldentey KM. and Piñol MT. Alkaloid production in Duboisia hybrid hairy roots and plants overexpresing the h6h gene. Plant Sci. 2003, 165: 1289-95.

92. Aehle E. and Draeger B. Tropane alkaloid analysis by chromatographic and electrophoretic techniques: an update. J Chromatogr B. 2010; 1391-406. doi:10.1016/j.jchromb. 2010.03.007

93. Bieri S, Brachet A, Veuthey J-L, and Christen P. Cocaine distribution in wild Erythroxylum species. J Ethnopharmacol. 2006; 439-47. doi:10.1016/j.jep. 2005.08.021

94. Kaufmann B, and Christen P.Recent extraction techniques for natural products: microwaveassisted extraction and pressurized solvent extraction. Phytochem Anal. 2002; 105-13. doi:10.1002/pca.631.
95. Brachet A, Rudaz S, Mateus L, Christen P, and Veuthey J-L Optimization of accelerated solvent extraction of cocaine and benzoylecgonine from Coca leaves. $J$ Sep Sci. 2001; 865-73. doi:10.1002/1615-9314 (20011101) 24: 10/11

96. Choi YH, Chin Y-W, Kim J, Jeon SH.and Yoo K-P. Strategies for supercritical fluid extraction of hyoscyamine and scopolamine salts using basified modifiers. J Chromatogr, A. 1999; 47-55. doi:10.1016/s0021-9673 (99) 00962-0.

97. Brachet A, Christen P, Gauvrit JY, Longeray R, Lanteri P.and Veuthey JL. Experimental design in supercritical fluid extraction of cocaine from coca leaves. J Biochem Biophys Methods. 2000; 353-66. doi: 10.1016/s0165-022x (00) 00062-2.

98. Brachet A, Mateus L, Cherkaoui S, Christen P, Gauvrit JY, Lanteri P. and Veuthey JL. Application of central composite designs in the supercritical fluid extraction of tropane alkaloids in plant extracts. Analysis. 1999; 772-8. doi: 10.1051/analusis: 1999143.

99. Leicach SR, Chludil HD. and Yaber GMA. Chromatography and spectroscopy of alkaloids. Science Publishers, Enfield, NH, USA. 2009; 175201. doi: 10.1201/b10195-10.

100. Cardillo AB, Talou JR, and Giulietti AM.Expression of Brugmansia candida Hyoscyamine 6beta-Hydroxylase gene in Saccharomyces cerevisiae and its potential use as biocatalyst. Microb Cell Fact: 2008; 7: 17. https://doi.org/10.1186/1475-2859-7-17.

101. Andreola B, Piovan A, Da DL, Filippini R. and Cappelletti E.Unilateral mydriasis due to Angel's trumpet. Clin Toxicol. 2008; 329-31.

102. Pramod KK, Singh S, and Jayabaskaran C. Expression of hyoscyamine 6b-hydroxylase in the root pericycle cells and accumulation of its product scopolamine in leaf and stem tissues of Datura metel L. Plant Sci. 2009; 178, 202-6. doi:10.1016/j.plantsci. 2009.11.004

103. Hosseini N, Ebrahimi SN, Salehi P, Asghari B. and Ahmadi M Simultaneous determination of

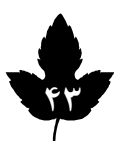


atropine and scopolamine in different parts of Hyoscyamus arachnoideus Pojark plants by highperformance liquid chromatography (HPLC). $J$ Med Plants Res. 2011; 5: 3552-57.

104. Ibrahim AI, Abd EKM, Nower A, Abdel $\mathrm{MA}$, and Abd EAA.Alkaloid production and organogenesis from callus of Hyoscyamus muticus L. in vitro. J Appl Sci Res. 2009; 5: 82-92.

105. Bahmanzadegan A, Sefidkon F.and Sonboli A. Determination of hyoscyamine and scopolamine in four Hyoscyamus species from Iran. Iran $J$ Pharm Res. 2009; 8 (1): 65-70.

106. Aehle E, and Dräger B. Tropane alkaloid analysis by chromatographic and electrophoretic techniques: An update. J. Chromatography $B$. 2010; 878 (17-18): 1391-406.

107. Muzquiz M. Separation of alkaloids by gas chromatography. In: Wilson ID, Adlard ER, Cooke M, Poole CF (eds) Encyclopedia of separation science. Academic, San Diege. 2000, pp: 1938-49.

108. Namera A, Yashiki M, Hirose $Y$, Yamaji S, Tani T, Kojima T. 2002. Quantitative analysis of tropane alkaloids in biological materials by gas chromatography-mass spectrometry. Forensic Sci Int.; 130: 34-43
109. Hartmann T, Witte L, Oprach F, Toppel G. Reinvestigation of the alkaloid composition of Atropa belladonna plants, root cultures, and cell suspension cultures. Planta Med. 1986; 390-5. doi: 10.1055/s-2007-969194.

110. Altria $K$, Marsh $A$, and Sanger-van GC. Capillary electrophoresis for the analysis of smallmolecule pharmaceuticals. Electrophoresis. 2006; 27, 2263-82. doi:10.1002/elps.200600030.

111. Ganzera M. Quality control of herbal medicines by capillary electrophoresis: potential, requirements and applications. Electrophoresis. 2008; 29: 3489-503. doi:10.1002/elps.200700901.

112. Cucinotta V, Contino A, Giuffrida A, Maccarrone G, and Messina M. Application of charged single isomer derivatives of cyclodextrins in capillary electrophoresis for chiral analysis. $J$ Chromatogr A. 2010; 1217 (7): 953-67. doi:10.1016/j.chroma.2009.11.094

113. Ren $X$, Ma Y, Zhou M, Huo S, Yao J, and Chen H. Determination of tropane alkaloid components in Przewalskia tangutica Maxim. by capillary electrophoresis with electrochemiluminescence detection. Se Pu. 2008; 26: 223-7. doi:10.1016/s1872-2059 (08) 60015-2. 
نوهسى و همكاران

\title{
A Comprehensive Overview on Valuable Tropane Alkaloids: Scopolamine, Atropine, and Hyoscyamine
}

\author{
Navasi F (M.Sc) ${ }^{1}$, Naghdi Badi H (Ph.D.) $)^{2}$, Mehrafarin A (Ph.D.) ${ }^{2}$, Rezazadeh Sh (Ph.D.) ${ }^{2}$, \\ Mustafavi Sh (Ph.D.) $)^{2}$, Ghorbanpour M (Ph.D. $)^{3}$ \\ 1- Department of Horticulture, Science and Research Branch, Islamic Azad University \\ (IAU), Tehran, Iran \\ 2- Medicinal Plants Research Center, Institute of Medicinal Plants, ACECR, Karaj, Iran \\ 3- Department of Medicinal Plants, Faculty of Agriculture and Natural Resources, Arak \\ University, Arak, Iran. \\ *Corresponding author: Medicinal Plants Research Center, Institute of Medicinal Plants, \\ ACECR, 55th Kilometer of Tehran-Qazvin Freeway, Karaj, P.O.Box: 31375-1369, Iran \\ Tel: +98-26-34764010-19, Fax: +98-26-34764021 \\ E-mail: A.Mehrafarin@gmail.com
}

\begin{abstract}
Tropane alkaloids such as scopolamine $\left(\mathrm{C}_{17} \mathrm{H}_{21} \mathrm{NO}_{4}\right)$, atropine $\left(\mathrm{C}_{17} \mathrm{H}_{23} \mathrm{NO}_{3}\right)$ and hyoscyamine $\left(\mathrm{C}_{17} \mathrm{H}_{23} \mathrm{NO}_{3}\right)$ are the most important plant secondary metabolites in the pharmaceutical industry due to anticholinergic activity, competition with muscarinic receptors and also treating different human diseases. Scopolamine, hyoscyamine and atropine are the most important tropane alkaloids used as anticoagulants and spasmolytic drugs in the digestive system and urinary excretion. Tropane alkaloids are natural phytochemical compounds, which are present in different plant families. These compounds are the main secondary metabolites in Solanaceae family plants such as Hyoscyamus niger and Atropa belladonna. The main source of raw material for the production of tropane alkaloids in the world is Duboisia spp. leaves which contain $\mathbf{2 - 4 \%}$ alkaloids (more than $60 \%$ scopolamine, and 30\% hyoscyamine). Common methods of analysis of tropane alkaloids include gas chromatography (GC), high-performance liquid chromatography (HPLC) and capillary electrophoresis (CE), in which liquid chromatography is mostly adopted. Various enzymes involved in the biosynthesis of tropane alkaloids, in which $N$-Putrescine methyltransferase (PMT), tropinone reductase I and II, and hyoscyamine 6-beta-hydroxylase (H6H) have a key role. To increase the biosynthesis of these important alkaloids, many studies were focused on the manipulation of key genes expressing enzymes in the biosynthesis pathway such as pmt and $h 6 h$ genes. Although many biotechnological and agronomic studies have been done to increase the biosynthesis efficiency of these metabolites, further investigations are necessary. This paper is intended to provide a comprehensive overview of these tropane alkaloids.
\end{abstract}

Keywords: Atropine, Hyoscyamine, Scopolamine, Tropane alkaloids 